\title{
Genetic and cell biological analysis of integrin outside-in signaling
}

\author{
Kyle R. Legate, ${ }^{1}$ Sara A. Wickström, ${ }^{1}$ and Reinhard Fässler ${ }^{2}$ \\ Department of Molecular Medicine, Max Planck Institute of Biochemistry, Martinsried 82152, Germany
}

Integrins are cell surface transmembrane receptors that recognize and bind to extracellular matrix proteins and counter receptors. Binding of activated integrins to their ligands induces a vast number of structural and signaling changes within the cell. Large, multimolecular complexes assemble onto the cytoplasmic tails of activated integrins to engage and organize the cytoskeleton, and activate signaling pathways that ultimately lead to changes in gene expression. Additionally, integrin-mediated signaling intersects with growth factor-mediated signaling through various levels of cross-talk. This review discusses recent work that has tremendously broadened our understanding of the complexity of integrin-mediated signaling.

The organization of multicellular organisms is a tightly controlled series of events. Tissues and organs have distinct characteristics and architecture, which result from specific interactions between cells and their environment, and with each other. Cells create their environment by secreting and manipulating extracellular matrix (ECM) components into the correct configuration to support the development of all structures that comprise a functioning organism. The major cell surface receptors that cells use to assemble and recognize a functional ECM are integrins. Integrins are heterodimers composed of $\alpha$ and $\beta$ subunits. Eighteen $\alpha$ subunits and eight $\beta$ subunits can assemble in 24 different combinations that have overlapping substrate specificity and cell-type-specific expression patterns (Hynes 2002; Humphries et al. 2006). The composition of integrins expressed by a cell determines to which ECM components that cell can bind.

Gene deletion studies in higher eukaryotes assigned important functions to integrin classes for a vast number of developmental processes. Since higher eukaryotes encode a large number of integrin subunits, analysis of individual knockout phenotypes is often complicated due to redundancy of function (Bouvard et al. 2001), but lower eukaryotes expressing fewer integrin subunits confirm the developmental importance of integrins. Caenorhabditis

[Keywords: Integrin signaling; actin cytoskeleton; growth factor receptors; cell adhesion]

${ }^{1}$ These authors contributed equally to this work.

${ }^{2}$ Corresponding author.

E-MAIL faessler@biochem.mpg.de; FAX 49-89-8578-2422.

Article is online at http://www.genesdev.org/cgi/doi/10.1101/gad.1758709. elegans possesses a single $\beta$ subunit, $\beta$ Pat- 3 , and two $\alpha$ subunits, ina-1 and pat-2 (Cox et al. 2004). Disruption of $\beta$ Pat -3 or Pat- 2 expression results in a paralyzed, arrested elongation at twofold (Pat) phenotype, characterized by detachment of muscles from the body wall upon their first contractions (Williams and Waterston 1994; Gettner et al. 1995), whereas disruption of ina-1 results in a milder defect, characterized by aberrant muscle cell migration and a "notched head," reminiscent of a dorsal closure defect (Baum and Garriga 1997; Tucker and Han 2008). Disruption of the $\beta 1$ ortholog in Drosophila, $\beta$ PS, also results in muscle attachment and dorsal closure defects (Brown 1994). Chimeric adult flies develop wing blisters in regions lacking $\beta P S$, illustrating the importance of integrins to attach cells to the ECM. Null mutations in two Drosophila $\alpha$ integrin subunits, $\alpha$ PS1 and $\alpha$ PS2, have less severe phenotypes but still display characteristics of defective cell attachment and disrupted midgut morphogenesis (Brabant and Brower 1993; Brown 1994; Brower et al. 1995).

Taken together, integrin deletions in several organisms point to a crucial role for integrins in attaching cells to the ECM, and thereby facilitating tissue morphogenesis during development. Integrin-mediated adhesion regulates cell migration, survival, cell cycle progression, and can modulate differentiation pathways. Therefore, signals that regulate these events must emanate from integrins; they are clearly more than just simple receptors mediating physical attachment of cells to their environment.

\section{Integrins signal bidirectionally}

Integrins are unusual among transmembrane receptors in that they signal bidirectionally-that is, not only can information flow from extracellular stimuli to induce intracellular changes (outside-in signaling), but intracellular stimuli can also cause extracellular changes (insideout signaling). The best studied example of inside-out signaling is the activation of integrins themselves. Integrins are normally expressed on the cell surface in an inactive conformation, unable to productively bind to ECM or counter receptors. This is particularly important for immune cells, which circulate through the bloodstream with minimal interactions with the vessel wall, and platelets, in which inappropriate integrin activation can lead to potentially life threatening thrombosis. Integrin-independent 
signals such as T-cell receptor activation (Burbach et al. 2007), ligation of selectins on neutrophils (Green et al. 2004), and glycoprotein VI on platelets binding to exposed collagen (Varga-Szabo et al. 2008) initiate signaling cascades that lead to integrin activation by promoting the translocation of talin and kindlin to $\beta$ integrin cytoplasmic tails. Talin binding is believed to represent the final common step in integrin activation (Tadokoro et al. 2003). Abrogation of talin-1 expression results in impaired integrin activation in a variety of cell types (Simonson et al. 2006; Lim et al. 2007; Nieswandt et al. 2007; Petrich et al. 2007). Recently, kindlin has also been found to be essential for integrin activation, but the pathways leading to its recruitment to integrin tails remain to be studied ( $\mathrm{Ma}$ et al. 2008; Montanez et al. 2008; Moser et al. 2008; Ussar et al. 2008).

Integrin activation increases the affinity of individual integrins for ECM ligands, but for a cell to bind strongly to ECM requires increasing the avidity of the interaction by clustering integrins so that hundreds, or thousands, of weak interactions sum into a tightly bound adhesive unit. Ligand-bound integrins cluster first into unstable structures called nascent adhesions (Choi et al. 2008). A subset of nascent adhesions progresses to dot-like focal complexes, which can mature into larger focal adhesions (FAs) and finally into streak-like fibrillar adhesions (Geiger et al. 2001). Once integrins are activated and clustered they are able to transmit the vast array of intracellular changes collectively referred to as "outside-in" signaling.

Immediate intracellular changes arising from integrin activation are increased tyrosine phosphorylation of specific substrates and an increase in the concentrations of lipid second messengers such as phosphatidylinositol (PtdIns)-4,5-bisphosphate (PtdIns-4,5- $\mathrm{P}_{2}$ ) and PtdIns-3,4,5$\mathrm{P}_{3}$ (Ferrell and Martin 1989; Golden et al. 1990; McNamee et al. 1993; Chen and Guan 1994). Short-term changes consist of cytoskeletal rearrangements that allow cells to adopt their characteristic shape and initiate migration via dynamic connections between integrins and filamentous (F-) actin. Long-term attachment to ECM results in changes in signaling pathways and gene expression that influence the survival, growth, and differentiation of cells (Fig. 1). Interestingly, these developmental programs are strongly influenced by mechanical properties of the matrix such as rigidity and tensile strength, implying that the major contribution of integrins to intracellular signaling results from changes in cytoskeletal organization and the application and modulation of intracellular force (Engler et al. 2006; Even-Ram et al. 2006; Ingber 2006). This review focuses on our current understanding of how integrinmediated outside-in signaling organizes the cytoskeleton and influences signal transduction pathways in response to ECM-attachment, and how integrins cross-talk with other signaling hubs with overlapping functions, to achieve an integrated response to extracellular stimuli.

\section{Assembly of the signaling platform}

Integrin activation is accomplished by large conformational changes in integrins, which has been proposed to

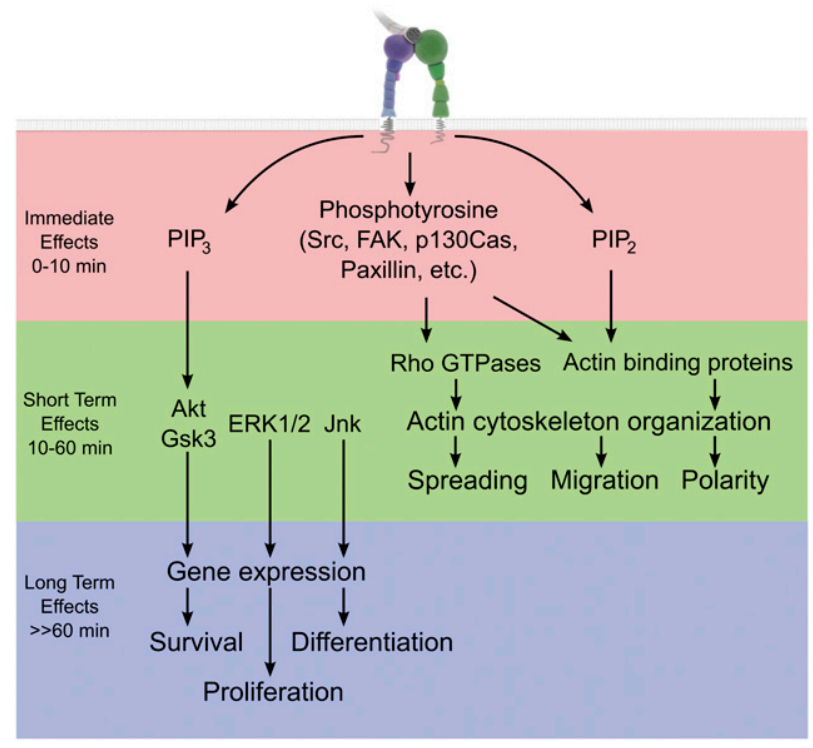

Figure 1. Consequences of integrin activation. Integrin activation leads to downstream signaling events that can be divided into three temporal stages. The immediate effects of integrin activation are the up-regulation of lipid kinase activity that increases the concentrations of the phosphoinositide second messengers PtdIns-4,5- $\mathrm{P}_{2}$ and PtdIns-3,4,5- $\mathrm{P}_{3}$, and the rapid phosphorylation of specific protein substrates, particularly at the nascent adhesion itself. Within several minutes these immediate effects then lead to the activation of signaling pathways and the activation of Rho family GTPases and other actin regulatory proteins, which drive the reorganization of the actin cytoskeleton. Long-term consequences of integrin activation ultimately lead to the activation of proliferation and survival pathways, and the induction of genetic programs to control cell morphology.

include the swinging-out of the hybrid domain in the extracellular region to expose the ligand-binding site (Xiao et al. 2004; Luo et al. 2007). Due to a lack of high resolution structural data the fate of the transmembrane and intracellular domains is still largely theoretical, but it is widely recognized that activation is achieved by separating the $\alpha$ and $\beta$ cytoplasmic tails as a consequence of talin binding to $\beta$ integrin membrane proximal sequences (Wegener et al. 2007; Wegener and Campbell 2008). As integrin tails have no catalytic activity of their own, they must bind accessory molecules that contribute cytoskeletal reorganizing and catalytic activity to the FA. Database mining combined with an extensive literature search recently identified 156 signaling, structural, and adaptor molecules that comprise the "integrin adhesome" (Zaidel-Bar et al. 2007), and more have since been discovered.

Many molecules have been shown to bind to isolated integrin tails directly (Legate and Fässler 2009). The composition of integrin-bound proteins can have profound effects on the signaling properties of integrins since they provide binding sites for additional members of the adhesome. Whether a given protein can bind to integrin tails is often determined by post-translational modification of 
the tails themselves. Phosphotyrosine-binding (PTB) domain-containing proteins recognize two NXXY motifs within a subset of $\beta$ tails (Calderwood et al. 2003); phosphorylation of these motifs by Src controls the binding pattern of proteins (Oxley et al. 2008; Legate and Fässler 2009). Phosphorylation of the membrane distal NXXY motif also inhibits cleavage of the Srcbinding site on the $\beta 3$ tail by the protease calpain $(\mathrm{Xi}$ et al. 2006). Additionally, phosphorylation of Ser/Thr residues on integrin tails by protein kinase $\mathrm{C}$ isoforms (Freed et al. 1989; Hibbs et al. 1991), Akt and PDK1 (Kirk et al. 2000), and ERK2 (Lerea et al. 2007) regulates the binding of adaptors such as filamin and 14-3-3 isoforms (Takala et al. 2008), which has significant effects on cell migration (Calderwood et al. 2001; Han et al. 2001; Fagerholm et al. 2005).

Phosphorylation of integrin-associated molecules is extremely robust; antibodies against phosphotyrosine can clearly distinguish adhesion complexes in their early stages when used as immunofluorescence probes (Maher et al. 1985). Phosphorylation of integrin-bound molecules can create binding sites for additional proteins that can significantly affect cell behavior. The recruitment of the adaptor molecule Crk to FAs serves as an interesting illustrative example. Early in adhesion, the integrin adaptor paxillin is tyrosine-phosphorylated by Src and FA kinase (FAK) (Bellis et al. 1995; Schaller and Parsons 1995), which creates a binding site for Crk (Turner 2000). p130 Crk-associated substrate (p130Cas) can be phosphorylated within FAs in response to mechanical stretch, which in turn creates docking sites for binding partners including Crk (Tamada et al. 2004; Defilippi et al. 2006; Sawada et al. 2006). Although both phosphoproteins bind to Crk, phosphorylation of paxillin and p130Cas has an antagonistic effect on haptotactic cell migration such that phosphorylated paxillin suppresses migration whereas phosphorylated p130Cas enhances migration (Yano et al. 2000). This probably results from Rac activation downstream from a p130Cas-Crk complex (Klemke et al. 1998), which has not been reported for a paxillin-Crk complex. In addition to controlling the assembly of signaling platforms within the FA, tyrosine phosphorylation also activates adhesion-associated kinases, such as FAK and Src (Boerner et al. 1996; Mitra et al. 2005). However, the roles of many phosphorylation events at adhesion sites are still mysterious. For example, mass spectroscopic analysis of talin isolated from activated platelets identified 30 different phosphorylation sites, three with high stochiometry (Ratnikov et al. 2005), but a biological role for talin phosphorylation has yet to be shown.

The incorporation of some proteins into the signaling platform is regulated by binding to phosphoinositides. The lipid kinase phosphatidylinositol 4-phosphate 5-kinase type I $\gamma$ (PIPKI $\gamma$ ) localizes to FAs via an interaction with talin (Di Paolo et al. 2002; Ling et al. 2002), and may generate a local elevation in PtdIns-4,5- $\mathrm{P}_{2}$ concentration at adhesion sites. Several FA-localized PTB domaincontaining proteins bind to PtdIns-4,5- $\mathrm{P}_{2}$, including Numb, Shc, tensin, and talin (Ravichandran et al. 1997;
Dho et al. 1999; Goksoy et al. 2008; Leone et al. 2008); talin binding to $\beta 1$ integrin is enhanced upon binding PtdIns-4,5- $\mathrm{P}_{2}$ (Martel et al. 2001). PI-3-kinase is also localized to FAs, and PI-3-kinase activity is increased in response to integrin activation (Chen and Guan 1994). PtdIns-3,4,5- $\mathrm{P}_{3}$ has a restructuring role in FAs by binding to $\alpha$-actinin and stimulating the dissociation of $\alpha$-actinin and vinculin from FAs (Greenwood et al. 2000). Although both PtdIns-4,5- $\mathrm{P}_{2}$ and PtdIns-3,4,5- $\mathrm{P}_{3}$ disrupt actin bundling activity of $\alpha$-actinin, only PtdIns-3,4,5- $\mathrm{P}_{3}$ disrupts the $\alpha$-actinin- $\beta$ integrin interaction (Greenwood et al. 2000; Corgan et al. 2004). The above study elicited $\alpha$-actinin redistribution by treating cells with plateletderived growth factor (PDGF). Since increased PI-3kinase activity is a common consequence of growth factor receptor (GFR) activation, rearrangement of FA composition may represent a common approach by which GFRs influence cell adhesion and migration.

\section{Connections to the cytoskeleton and regulation of FA growth}

The integrin-cytoskeleton linkage is a network of transient, highly dynamic interactions between FA proteins and F-actin, which facilitates the connection of the relatively static, ECM-bound integrins to the constantly rearward treadmilling F-actin network. FA proteins involved in establishing and maintaining the integrincytoskeleton linkage can roughly be divided into four classes: (1) integrin-bound proteins that directly bind actin, such as talin, $\alpha$-actinin, and filamin; (2) integrinbound proteins that indirectly associate with/regulate the cytoskeleton such as kindlin, integrin-linked kinase (ILK), paxillin, and FAK; (3) non-integrin-bound actinbinding proteins, such as vinculin; and (4) adaptor and signaling molecules that regulate the interactions of the proteins from the above-mentioned groups. Experiments utilizing novel imaging technologies such as total internal reflection fluorescence (TIRF) microscopy and fluorescent speckle microscopy, in combination with structural, biochemical, and in vivo data, point to talin, vinculin, $\alpha$-actinin, and ILK as the crucial structural elements of the integrin-actin linkage, as well as the main components regulating FA growth. Other proteins such as FAK and paxillin play a more modulatory role through their enzymatic or scaffolding activities. The exact position of kindlin in this hierarchy is yet to be established.

\section{Talin: the initial contact to the cytoskeleton}

The initial integrin-cytoskeleton linkage following fibronectin binding involves the recruitment of talin to $\beta$ integrins and the establishment of a 2-pN slip bond, which provides the initial force applied by the cytoskeleton to the extracellular ligand (Jiang et al. 2003). Consequently, undifferentiated embryonic stem cells lacking talin-1 or fibroblasts lacking both talin- 1 and talin-2 are unable to link integrins to the cytoskeleton (Priddle et al. 1998; Zhang et al. 2008). This effect cannot be explained solely by the integrin activating function of talin, since 
reintroduction of the talin head domain, sufficient for integrin activation, does not rescue the cytoskeletal linkage in talin-null cells. The requirement of the talin rod domain responsible for the majority of talin's actinbinding activity, together with the inability of talin-null cells to spread, collectively suggests that talin functions as a direct mechanical linkage between integrins and the actin cytoskeleton (Tanentzapf and Brown 2006; Zhang et al. 2008). The importance of talin in connecting integrins to the actin cytoskeleton is underlined by in vivo studies in various organisms. Mice lacking talin1 die during gastrulation due to a defect in cytoskeletal organization and cell migration (Monkley et al. 2000). In flies lacking talin, integrins are able to associate with the ECM but are unable to connect to the cytoskeleton, leading to muscle detachment (Brown et al. 2002). Lossof-function studies in C. elegans have confirmed the role of talin in stabilizing strong adhesive contacts in muscle as well as in regulating dynamic integrin-actin interactions during cell migration (Cram et al. 2003).

\section{Vinculin: reinforcing the linkage}

Talin binding is rapidly followed by the recruitment of proteins such as vinculin to the nascent adhesion. Vinculin may be the major player in the growth and maturation of FAs. Vinculin binds to several sites in the talin rod (Critchley and Gingras 2008) that are normally buried in helical bundles but may become exposed upon mechanical stretch (Papagrigoriou et al. 2004; Fillingham et al. 2005; Lee et al. 2007). Further stretching could expose additional cryptic sites to recruit more vinculin to adhesions (Gingras et al. 2005). Expressing the talin head domain, which does not bind vinculin, in talin-null cells activates integrins but fails to form detectable focal contacts (Zhang et al. 2008). Vinculin ${ }^{-1-}$ fibroblasts make fewer, smaller, and more unstable adhesions compared with cells expressing vinculin (Saunders et al. 2006), perhaps due to the ability of full-length talin to cross-link activated integrins and provide a few direct linkages to actin (Critchley and Gingras 2008). However, these adhesions are unable to mature in the absence of vinculin. Thus, it is evident that talin makes the initial contacts between integrins and actin, but it is not sufficient to maintain this connection on its own. Vinculin is required to strengthen the linkage by acting as a cross-linker and stabilizing the talin-actin interaction by binding directly to both proteins (Gallant et al. 2005; Humphries et al. 2007). Disrupting the actin inhibitory PtdIns-4,5-P $\mathrm{P}_{2}$-binding site on vinculin results in extraordinarily stable FAs, suggesting that the connection between vinculin and actin is required for FA stability (Saunders et al. 2006). However, expressing only the vinculin head domain, which binds to talin but uncouples FAs from actin filaments, results in larger-than-average FAs, suggesting that the vinculin-talin interaction alone is responsible for FA growth (Humphries et al. 2007). The mechanism for this is unknown, but it is possible that the bound vinculin head domain stabilizes the open, active conformation of talin, allowing it to cluster integrins more efficiently.
$\alpha$-Actinin: actin cross-linking and adhesion strengthening

Recent studies have highlighted the importance of $\alpha$ actinin, a binding partner of both talin and vinculin, in linking integrins to the cytoskeleton. Despite its ability to directly bind $\beta$ integrins (Otey et al. 1990; Pavalko and LaRoche 1993), it is more likely that $\alpha$-actinin operates as a close partner of actin in modulating the strength and stability of the integrin-actin linkage (Brown et al. 2006; Choi et al. 2008). Consequently, the force-dependent strengthening of integrin-cytoskeleton linkages correlates with the incorporation of $\alpha$-actinin into integrin adhesion sites (Laukaitis et al. 2001; von Wichert et al. 2003a). $\alpha$-actinin has been shown to have an essential role in adhesion strengthening in vivo. In Drosophila, $\alpha$-actinin-null mutations are lethal due to defects in muscle structure and function (Fyrberg et al. 1998). Mammals express four isoforms of $\alpha$-actinin: the striated musclespecific $\alpha$-actinin- 2 and $\alpha$-actinin-3, and the more widely expressed $\alpha$-actinin- 1 and $\alpha$-actinin- $4 . \alpha$-Actinin- 2 and $\alpha$-actinin-3 cross-link actin filaments in the region of $\mathrm{Z}$ discs in striated muscles where they regulate force coupling of muscle fibers (MacArthur et al. 2007, 2008), whereas $\alpha$-actinin- 4 is essential for kidney function both in mice and in humans by strengthening the adhesion of podocytes to the glomerular basement membrane (Kaplan et al. 2000; Kos et al. 2003; Dandapani et al. 2007). $\alpha$-actinin-4 also localizes to the slit diaphragm where it binds to nephrin (Lehtonen et al. 2005; Dai et al. 2006), which might explain why $\alpha$-actinin-1, despite being expressed in the kidney, is unable to compensate for $\alpha$-actinin-4 in this tissue.

\section{ILK: a core scaffold}

ILK is a multidomain adaptor protein that binds directly to $\beta 1$ and $\beta 3$ integrins, and associates indirectly with actin through its main binding partner parvin. Additional connections between ILK and the cytoskeleton can also form through paxillin, which in turn binds to parvin and vinculin (Legate et al. 2006). ILK-deficient fibroblasts display a severe delay in the formation of FAs, resulting in a defect in cell spreading. Once established, the FAs are smaller in size and poorly linked to a disorganized actin cytoskeleton (Sakai et al. 2003). The essential role of ILK in stabilizing the integrin-actin interaction in vivo becomes particularly evident in the myotendinous junction of nonvertebrate muscle tissue, where muscle contraction creates stringent requirements for a stable adhesion-cytoskeleton linkage. Deletion of ILK in C. elegans, Drosophila, or zebrafish leads to muscle detachment from the body wall due to the detachment of actin from the plasma membrane (Zervas et al. 2001; Mackinnon et al. 2002; Postel et al. 2008). In ILK-deficient mice, muscle detachment occurs at the level of the integrin-ECM interaction (Wang et al. 2008), suggesting that ILK regulates adhesion strength by reinforcing the integrin-actin connection and thus stabilizing the clustered state of integrins. 


\section{Integrin-actin modulators}

FAK is a signaling protein shown to bind to $\beta$ integrins via its N-terminal FERM domain in vitro (Schaller et al. 19951, but the association of FAK with integrins in vivo is currently believed to be indirect occurring most likely through paxillin (Hayashi et al. 2002; G. Liu et al. 2002). FAK is dispensable for the formation of nascent FAs or their initial connection to the actin cytoskeleton but is required to stabilize the linkage (Ilic et al. 1995). Mechanistically, this might occur via FAK-mediated phosphorylation of $\alpha$-actinin, which has been shown to modulate its affinity to actin (Izaguirre et al. 2001). FAK, however, seems to play an essential role in promoting FA turnover. Cells deficient in FAK have enlarged FAs and migrate with reduced speed, consistent with the requirement for FA turnover to promote cell motility (Mitra et al. 2005).

Recent work has revealed an essential role for kindlins in activating integrins and linking them to actin. Kindlins have been shown to directly bind $\beta 1$ and $\beta 3$ integrins and to connect to the actin cytoskeleton via a migfilin-filamin interaction as well as through the ILK-parvin complex (Tu et al. 2003). Deletion of UNC-112, the nematode ortholog of the mammalian kindlins, leads to a Pat phenotype identical to that seen when PAT-3/ $\beta$ integrin or PAT-4/ILK are deleted (Rogalski et al. 2000). In mice, platelets lacking Kindlin-3 expression are unable to organize their cytoskeleton or establish stable lamellipodia upon $\mathrm{Mn}^{2}$-triggered integrin ligation (Moser et al. 2008). In addition, loss of Kindlin-2 results in early embryonic lethality and impaired actin organization and FA formation in endoderm cells, most likely through impaired recruitment of proteins such as ILK to the adhesion plaque (Montanez et al. 2008), while loss of Kindlin-1 results in shear-induced detachment of intestinal epithelial cells (IEC) in the distal colon, leading to death $\sim 3 \mathrm{~d}$ after birth (Ussar et al. 2008). Cell biological assays on isolated IECs indicate that integrin activation is impaired in these cells.

Other important integrin-actin regulatory proteins include paxillin and tensin. Paxillin is one of the earliest proteins to be detected in nascent adhesions at the leading edge of the cell. Its structure allows numerous simultaneous interactions, which are further modified by phosphorylation, facilitating the function of paxillin as a molecular platform regulating the integrin-actin linkage through the modulation of FA composition (Laukaitis et al. 2001; Digman et al. 2008). Interestingly, paxillin might also link talin to the cytoplasmic tail of $\alpha$ integrins, thereby increasing the stability of the integrin-talinactin interaction (Alon et al. 2005).

In contrast to paxillin, tensin is recruited to FAs rather late in several cell types (Zamir et al. 1999). Tensin couples integrins to actin via two $\mathrm{N}$-terminal actinbinding domains and acts as a cross-linker between these two proteins (Lo et al. 1994). Its C-terminal SH2 domain on the other hand interfaces with signaling pathways through binding tyrosine-phosphorylated FAK, p130Cas, epidermal growth factor receptor (EGFR) (Cui et al. 2008), the Akt kinase PDK1 (Wavreille and Pei 2007), and the RhoGAPs deleted in liver cancer-1 (DLC-1) and DLC-3
(Liao et al. 2007; Qian et al. 2007). Cten is a tensin family member lacking the actin-binding domains (Lo and Lo 2002). Recent work has uncovered an EGF-regulated transcriptional switch involving tensin-3 and cten that regulates breast cancer cell migration in response to epidermal growth factor (EGF) treatment. Exposure of HeLa cells or MCF10A normal breast epithelia to EGF results in down-regulated tensin-3 expression and upregulation of cten expression, which is accompanied by the disassembly of actin stress fibers and increased cell migration. The contribution of this tensin-3-cten switch to actin reorganization and altered migratory behavior was confirmed by experiments in which knockdown of cten induced the enhanced formation of stress fibers and reduced migratory behavior, whereas knockdown of tensin-3 resulted in disintegration of stress fibers and increased cell migration. In contrast to these results, tensin-1-null and tensin-3-null mouse cells (fibroblasts and intestinal epithelia, respectively) exhibit migration defects, which can be restored in tensin-1-null cells by overexpressing either tensin-1 or tensin-2 (Chen et al. 2002; Chen and Lo 2003; Chiang et al. 2005). The reason for these differences is unknown but could reflect cell-typespecific requirements for tensin-mediated migration.

Analysis of the dynamic interactions between various FA components and F-actin using TIRF and fluorescent speckle microscopy has revealed a hierarchical correlation between the velocity of rearward movement of these proteins and their degree of connection to the ECM. Matrix-bound integrins have the slowest velocity, and proteins closely associated with integrins move at a similar speed. In contrast, proteins with a more indirect link to integrins but a tight connection to actin move with a higher velocity only slightly below that of the treadmilling actin. Talin and vinculin seem to exist at the interface of these two possibilities, suggesting that they undergo constant switching between F-actin- and integrinbound states, establishing a "slippage clutch" between the static matrix adhesions and the treadmilling actin (Hu et al. 2007). In this scenario, actin is constantly pulled by myosin, and strong association of integrins with F-actin will transmit the pulling forces to the ECM, whereas a weaker linkage leads to detachment of actin from integrins, allowing the cell body to slide over the adhesion. This would allow the precise, local regulation of cell motility on the level of the integrin-actin connection. Alternatively, the clutch has been proposed to represent a mechanism by which the cell can locally modulate the strength of the integrin-actin linkage in response to changes in the attachment strength to the ECM, either on the level of integrins, through talin and vinculin, or on the level of actin through $\alpha$-actinin (Brown et al. 2006). This would allow the cells to fine-tune the integrin-actin interaction in response to extracellular cues such as changes in ligand concentration.

\section{Actin bundling vs. force-mediated FA growth}

$\alpha$-actinin, in collaboration with myosin II, plays a critical role in the growth and maturation of FAs. The formation 
of nascent adhesions under the narrow, actin-rich lamellipodium does not require mechanical tension, but these adhesions are unstable and tend to disintegrate. However, a few mature into focal complexes and FAs dependent on the actin cross-linking activity of $\alpha$-actinin and myosin II (Choi et al. 2008). Surprisingly, maturation is not dependent on the contractile activity of myosin II, as a mutant version of myosin II lacking motor activity is sufficient to restore FA maturation in cells devoid of either endogenous myosin II or $\alpha$-actinin. According to this model, actin cross-linking by $\alpha$-actinin and myosin II is sufficient to induce the growth of FAs, but it is clear that externally applied force achieves the same result. Fluorescence microscopy has revealed that focal complexes mature into FAs in response to mechanical tension on an elastic micropatterened substrate (Balaban et al. 2001). Also, studies examining the incorporation of cytosolic proteins into Triton-solubilized cytoskeletons showed that FA components paxillin, FAK, p130Cas, and Akt were recruited to the cytoskeletal fraction in response to externally applied stretch (Sawada and Sheetz 2002). The application of external force to cells resulted in FA growth in several other studies (Riveline et al. 2001; Galbraith et al. 2002; Paul et al. 2008) and microscopic analysis found that adhesion formation was initiated during periodic contraction of actin in the lamellipodium (Giannone et al. 2007).

A general model to explain these findings begins to emerge. Actin stress fibers align and thicken in response to shear flow or cyclic mechanical stretch in an integrindependent fashion (Galbraith et al. 1998; Hayakawa et al. 2001). The effect of external force on FA growth may not be the force per se, but the actin cross-linking that is induced in response to force. This cross-linking is dependent on $\alpha$-actinin and myosin II but is not dependent on contractile activity of myosin II. The myosin IIA isoform is solely responsible for this activity under normal conditions in fibroblasts, as genetic ablation or siRNA knockdown of myosin IIA results in the loss of stress fibers and vinculin-containing FAs (Even-Ram et al. 2007). Cross-linking and bundling of actin filaments may promote the clustering of integrins within the membrane via adhesion components that connect integrins to F-actin. This clustering induces the accumulation of additional signaling partners that leads to the further growth of the adhesion plaque. The disintegration of FAs that commonly follows myosin II inhibition may not result from relieving the tension on the cytoskeleton, but rather from the concomitant actin unbundling that occurs.

\section{Regulation of actin dynamics}

In addition to regulating the growth of FAs, attachment of integrins to F-actin is critical for the precise spatiotemporal control of cell protrusion and retraction during cell migration, in the regulation of cell shape as well as during muscle contraction. At the leading edge of the cell actin forms the lamellipodium, a dendritic network within a thin leaflet of plasma membrane, which functions to initiate cell adhesion and to generate cell protrusion by de novo F-actin polymerization. Behind the lamellipodium the fast retrograde flow of polymerizing actin acquires contractile properties through the interaction of actin with myosin II in a structure called the lamellum (Small and Resch 2005). The boundary between the lamellum and lamellipodium is defined by the establishment of nascent adhesions; within seconds of nascent adhesion formation in the lamellipodium, actin flow behind the adhesion slows and the lamellar border advances (Alexandrova et al. 2008). It is these incremental advances in the lamellar border that lead to spreading and migration of cells.

The physical link between integrins and actin allows both local regulation of actin polymerization as well as global control of cytoskeletal dynamics. The molecular mechanisms by which integrins regulate local actin polymerization are beginning to emerge. It was recently shown that isolated integrin adhesions contain the complete machinery necessary for actin polymerization (Butler et al. 2006). A central molecular machine in this process is the Arp2/3 complex, which controls the assembly of a branched actin filament network in the lamellipodium through its actin nucleation function. However, the isolated Arp2/3 complex has no endogenous actin nucleating activity and must be activated by the Wiskott-Aldrich Syndrome protein (WASP)/Scar family of activator proteins (Pollard 2007). WASP binds and induces a conformational change in the Arp2/3 complex that permits the formation of a template for actin filament elongation (Robinson et al. 2001). Arp2/3 is recruited to nascent integrin adhesions through interactions with FAK as well as vinculin to promote actin polymerization, which in turn generates the protrusive force for the lamellipodium. FAK-deficient cells or cells in which the FAK-Arp2/3 complex has been disrupted display impaired lamellipodium formation and a spreading defect (Serrels et al. 2007). Vinculin binding appears to be more transient and is not required for cell motility or spreading, but might be necessary for the relocation of Arp2/3 to nascent adhesions (DeMali et al. 2002).

In the lamellum, actin is organized into bundles to establish directional persistence of cell motility. Here actin assembly is mediated by the diaphanous-related formin (DRF) protein family, which was shown to be essential for organization and dynamics of lamellar F-actin as well as for the turnover of FAs (Pruyne et al. 2002). DRFs localize to integrin adhesions and are indispensable for local actin assembly at these sites (Riveline et al. 2001; Butler et al. 2006). They are also responsible for generating dorsal stress fibers, contractile actomyosin bundles directly anchored to FAs. These structures are essential for cell adhesion and for changes in cell shape, particularly retraction of the trailing edge during migration (Cramer et al. 1997; Hotulainen and Lappalainen 2006).

Local actin polymerization is coupled to global regulation of actin dynamics by the Rho GTPases, which control the spatiotemporal regulation of the processes discussed in the previous paragraph. Mammalian Rho GTPases are a family of 20 signaling proteins, which cycle 
between an active GTP-bound form and an inactive GDPbound form. This cycling is regulated by three sets of proteins, guanine nucleotide exchange factors (GEFs), GTPase-activating proteins (GAPs), and guanine nucleotide dissociation inhibitors (GDIs) (Table 1). The recruitment and activation of GEFs and GAPs at FAs regulate the activities of the Rho GTPases to establish cell polarity and directional migration (Jaffe and Hall 2005). The most important GTPases for the regulation of actin dynamics at FAs are Rac, Cdc42, and RhoA.

\section{Rac: regulator of lamellipodium formation}

Integrin ligation and clustering lead to membrane targeting of Rac as well as recruitment of multiple GEFs via signaling modules such as the FAK-p130Cas-CrkDOCK180 pathway and the paxillin-GIT-PIX pathway (Fig. 2; Cary et al. 1998; Kiyokawa et al. 1998; del Pozo et al. 2004; Nayal et al. 2006), so new adhesions formed at the leading edge contain high levels of active Rac, which promotes lamellipodial protrusion. There are several ways by which Rac can regulate actin polymerization. It can activate the Arp2/3 complex via the Scar/WAVE proteins, activate DRFs, increase the availability of free actin barbed ends by the removal of capping proteins, or increase the availability of actin monomers by regulating cofilin (Jaffe and Hall 2005). Rac also feeds back to the integrins by promoting recruitment and clustering of activated integrins at the edge of the lamellipodium (Kiosses et al. 2001). The importance of the $\beta 1$ integrinRac axis for lamellipodia formation in vivo is demonstrated by the conditional knockouts of these molecules in Schwann cells. Cells from mice lacking $\beta 1$ integrin in Schwann cells show decreased Racl activity and are deficient in the extension of radial membranes required for axonal sorting and myelination. This defect can be partly rescued by expressing active Rac (Nodari et al. 2007) and is phenocopied by the conditional ablation of Racl in these cells (Benninger et al. 2007).

\section{Cdc42: regulator of cell polarity}

Genetic ablation studies have demonstrated that Cdc42 regulates cell polarity in hepatocytes (van Hengel et al.

Table 1. GTPases, GAPs, and GEFs found in FAs

\begin{tabular}{|c|c|c|}
\hline Molecule & Affects & References \\
\hline \multicolumn{3}{|l|}{ GTPases } \\
\hline$\overline{\operatorname{Cdc} 42}$ & Filopodial extension & Degani et al. 2002 \\
\hline Dynamin-2 & Actin remodeling & Kharbanda et al. 1995 \\
\hline Racl & Lamellipodial extension & van Hennik et al. 2003 \\
\hline Rap1 & RacGEF recruitment & Arthur et al. 2004 \\
\hline RhoA & Cytoskeletal retraction & \\
\hline \multicolumn{3}{|l|}{ GAPs } \\
\hline$\overline{\mathrm{AM}} \mathrm{AP} 1$ (ASAP2) & Arf & Y. Liu et al. 2002 \\
\hline AMAP2 (PAG3) & Arf & Kondo et al. 2000 \\
\hline APAP1 (Git1) & Arf & Premont et al. 2000 \\
\hline APAP2 (PKL/Git2) & Arf & Turner et al. 1999 \\
\hline ArhGAP5 & Rho & Burbelo et al. 1995 \\
\hline ASAP3 & Arf & Ha et al. 2008 \\
\hline CdGAP & Cdc42, Rac & LaLonde et al. 2006 \\
\hline DLC-1 & Rho & Liao et al. 2007 \\
\hline DLC-3 & Cdc42, Rho & Kawai et al. 2007 \\
\hline DOCK180 & $\operatorname{Rac}$ & Tu et al. 2001 \\
\hline ELMO & Rac & Grimsley et al. 2004 \\
\hline FilGAP & Rac & Ohta et al. 2006 \\
\hline Graf & Rho & Hildebrand et al. 1996 \\
\hline p120RasGAP & Ras & Bradley et al. 2006 \\
\hline p190RhoGAP & Rho & Bradley et al. 2006 \\
\hline RC-GAP72 & Cdc42, Rac1 & Lavelin and Geiger 2005 \\
\hline \multicolumn{3}{|l|}{ GEFs } \\
\hline$\alpha \mathrm{PIX}$ & Cdc42, Rac & Manser et al. 1998 \\
\hline$\beta P I X$ & Cdc42, Rac & Oh et al. 1997 \\
\hline AND-34 & R-Ras, Rap1, Ral & Cai et al. 1999 \\
\hline LARG & Rho & Dubash et al. 2007 \\
\hline Lsc/P115RhoGEF & Rho & Dubash et al. 2007 \\
\hline p190RhoGEF & Rho & Zhai et al. 2003 \\
\hline RapGEF1 (C3G) & Rap & Tanaka et al. 1994 \\
\hline Sos & Ras & Schlaepfer et al. 1994 \\
\hline Tiam1 & $\mathrm{Rac}$ & Arthur et al. 2004 \\
\hline Trio & Rho & Medley et al. 2003 \\
\hline Vav & Rho & Gao et al. 2005 \\
\hline
\end{tabular}




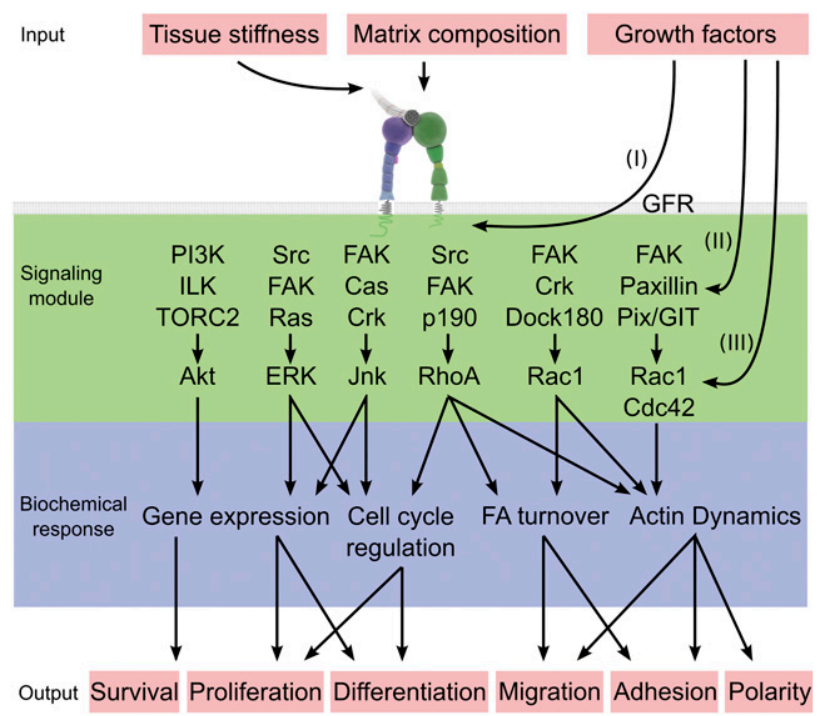

Figure 2. Examples of signaling pathways located downstream from integrin activation. The composition of the extracellular matrix, its mechanical properties, and the growth factor environment regulate the outside-in signaling by integrins in cooperation with growth factor receptors (GFR). Growth factor signaling interacts with integrin-mediated signaling on multiple levels: by regulating integrin affinity for ligands (I), by regulating the activity of the integrin-associated signaling proteins such as FAK, Src, and PI3K (II), and by regulating the activity of the downstream effectors such as ERK, Akt, JNK, and the Rho GTPases (III). The central signaling module downstream from integrins is the Src/FAK complex, which activates ERK and JNK to regulate cell survival, proliferation, and differentiation. In addition, through activation of Crk/Dock180 or alternatively PIX/GIT pathways, the Src/FAK complex regulates Rho GTPase activity, resulting in cytoskeletal reorganization and regulation of migration, adhesion, and polarity. Integrins also activate PI3K, which in collaboration with ILK and mTOR regulates cell survival through Akt. Cross-talk between the various pathways as well as alternative activation pathways are not depicted. (GFR) Growth factor receptor; (PI3K) PI-3-kinase; (ILK) integrin linked kinase; (TORC) mammalian target of rapamycin complex; (FAK) FA kinase; (ERK) extracellular signal-regulated kinase; (Cas) Crk-associated substrate; (JNK) Janus kinase; (DOCK180) dedicator of cytokinesis 1; (PIX) PAK interactive exchange factor; (GIT) G protein-coupled receptor kinase-interacting protein.

2008), neurons (Garvalov et al. 2007), and epithelia (Wu et al. 2006, 2007) but not in fibroblastoid cells, where other GTPases are also involved (Czuchra et al. 2005). Blocking integrins by using Arg-Gly-Asp (RGD) peptides or blocking downstream signaling by inhibiting Src activity leads to loss of Cdc42 activation and inhibition of cell polarity (Etienne-Manneville and Hall 2001). Integrin ligation has also been shown to activate Cdc42 via the ILK- $\beta$-parvin- $\alpha$ PIX pathway (Filipenko et al. 2005). Cdc 42 regulates polarity by activating Arp $2 / 3$ via WASP, which establishes sites for lamellipodium formation, as well as by orienting the microtubule-organizing center and Golgi apparatus in front of the nucleus, toward the leading edge (Jaffe and Hall 2005). As both Rac and
Cdc42 activate Arp $2 / 3$, it is not entirely clear why their activation leads to such morphologically distinct structures, lamellipodia and filopodia, respectively. However, recent studies on the morphogenesis of these structures have revealed that Cdc42-induced filopodia act as precursors for Rac-induced lamellipodia, establishing a temporal hierarchy of integrin-dependent Rho GTPase activation in the regulation of cell spreading and migration (Guillou et al. 2008).

\section{RhoA: regulator of cell contractility}

The RhoA GTPase promotes cell contractility through two key effector pathways: the Rho kinase, which promotes contractility by increasing phosphorylation of the regulatory light chain of myosin II, and the DRFs, which regulate actin bundling and microtubule stability (Fukata et al. 2003). Initial phases of cell adhesion or lamellipodial protrusion thus require suppression of RhoA activity. This can be achieved via integrin-mediated activation of c-Src or the kinase AblII/Arg, which in turn activate p190RhoGAP, or alternatively through activation of Rac1, which suppresses RhoA activity (Sander et al. 1999; Arthur et al. 2000; Arthur and Burridge 2001; Nimnual et al. 2003; Bradley et al. 2006). RhoA is later activated to induce the contraction necessary for retracting the trailing edge as well as for maturation of FAs.

A recent study suggests that RhoA activating and inactivating signals are regulated via a $\beta 3$ integrin cleavage switch mediated by calpain. A calpain-cleaved form of $\beta 3$ promotes contractility, whereas the full-length form promotes spreading due to the interaction of c-Src with the extreme $C$ terminus of the full-length $\beta 3$ integrin, which inhibits RhoA-dependent contractile signals. Thus, $\beta 3$ tail cleavage relieves c-Src-mediated RhoA inhibition and induces a transition from spreading to contraction (Flevaris et al. 2007). Whether an analogous mechanism applies for other $\beta$ integrins as well needs to be analyzed. Studies demonstrating that integrins $\alpha \mathrm{v} \beta 3$ and $\alpha 5 \beta 1$ differentially regulate RhoA activity in response to fibronectin binding suggest, however, that $\beta$ subunits do not employ identical strategies to regulate RhoA (Danen et al. 2002 ), perhaps due to different abilities of $\beta 1$ and $\beta 3$ to bind c-Src (Arias-Salgado et al. 2005). Another possibility is that the integrin $\alpha$ subunit plays a coregulatory role in the signaling from integrins to RhoA. It was shown in epithelial cells that collagen- $\alpha 2 \beta 1$ integrin binding activates RhoA, whereas laminin $322-\alpha 3 \beta 1$ integrin binding inhibits RhoA and activates PAK1, leading to opposing effects on cell motility (Zhou and Kramer 2005). Differential recycling of $\alpha v \beta 3$ and $\alpha 5 \beta 1$ to the cell surface can also influence Rho signaling, as increased $\alpha 5 \beta 1$ surface expression in response to impaired $\alpha v \beta 3$ trafficking results in enhanced Rho-ROCK-cofilin pathway activity and increased random migration (White et al. 2007). Taken together it seems that the pattern of integrin receptors expressed on a cell dictates the level and kinetics of RhoA activation. The generation of RhoA knockout mice will be required to assess the in vivo relevance of these findings. 


\section{Regulation of signal transduction}

Regulation of ligand-binding affinity by inside-out signaling, the localized nature of integrin signaling, and integration of mechanical and chemical signals through direct association with the cytoskeleton make integrins unique signaling machines. However, cross-talk between GFRs and integrins was demonstrated over a decade ago, suggesting that these two classes of signaling hubs often function together to achieve a desired outcome. Growth factor stimulation and integrin-mediated adhesion together increase the intensity (Miyamoto et al. 1996) and duration (Roovers et al. 1999) of extracellular signalregulated kinase (ERK) activation; in the absence of adhesion cues, growth factor-mediated ERK activation is transient (Roovers et al. 1999). While one report demonstrated that phosphorylation of EGFR and PDGF receptor (PDGFR) is enhanced when cells were treated with both growth factors and integrin ligands (Miyamoto et al. 1996), other reports have shown that integrin activation alone is sufficient to stimulate EGFR and PDGFR phosphorylation (Sundberg and Rubin 1996; Moro et al. 1998). Studies in fibroblasts showed that, upon integrin engagement, transient complexes containing EGFR, $\alpha v \beta 3$ integrin, p130Cas, and c-Src are assembled, resulting in EGFR phosphorylation in a c-Src- and endogenous EGFR kinase activity-dependent manner (Moro et al. 2002). Interestingly, the phosphorylation pattern on EGFR induced by this complex was distinct from the pattern induced by EGF binding. Mass spectrometric analysis of EGFR peptides from ECV304 endothelial cells revealed that adhesion-dependent phosphorylation sites on EGFR differ from growth factor-dependent phosphorylation sites (Boeri Erba et al. 2005), suggesting that GFRs have functions independent of growth factor binding but dependent on integrin-mediated adhesion. The dependence on endogenous kinase activity implies that integrin activation induces clustering of GFRs; indeed, such clustering has been observed for EGFR, PDGFR, and FGFR (Plopper et al. 1995; Miyamoto et al. 1996; Sundberg and Rubin 1996). The fact that GFRs can be activated in response to matrix binding suggests that the contribution of GFR-mediated signaling to what is thought to be primarily integrin-mediated signaling may be vastly underestimated. Adhesion-dependent Rac activation leading to cell spreading, for example, was shown to be dependent on intact EGFR signaling in COS cells, even in the absence of EGF (Marcoux and Vuori 2003).

\section{Src-FAK complex: switching on integrin signaling}

Assembling the current knowledge of integrin signaling pathways into a network connections map highlights the Src-FAK complex as the major hub for integrin signaling (Fig. 2; Martin et al. 2002; http://stke.sciencemag.org/cgi/ $\mathrm{cm} /$ stkecm;CMP_6880). Src is a nonreceptor tyrosine kinase constitutively associated with the cytoplasmic tail of $\beta 3$ integrins via its SH3 domains (de Virgilio et al. 2004; Arias-Salgado et al. 2005). It is the prototype Src family kinase (SFK), a family consisting of nine members, of which Src, Fyn, and Yes are ubiquitously expressed. All SFKs are regulated by a C-terminal tyrosine residue that, when phosphorylated, binds to the SH2 domain to autoinhibit kinase activity.

SFK activation, which is one of the earliest events following integrin ligation and clustering, can be achieved via several mechanisms. In case of the platelet $\alpha I I \beta 3$ integrin, integrin ligation causes the dissociation of the Src inhibitory kinase Csk from the integrin, leading to Src dephosphorylation at the inhibitory tyrosine 529. This induces a conformational change to allow autophosphorylation of the activating tyrosine 418 (Obergfell et al. 2002). Alternatively, the inhibitory tyrosine can be dephosphorylated by integrin-associated phosphatases such as RPTP $\alpha$ in response to $\alpha \mathrm{v} \beta 3$ ligation (den Hertog et al. 1993; von Wichert et al. 2003b) or PTP1B (Liang et al. $2005)$. The activation of $\beta 1-, \beta 2-$, and $\beta 3$-bound SFKs has also been shown to occur through transactivation of Src by itself or by competition from FAK for binding to the Src SH2 domain (Arias-Salgado et al. 2003; Mitra et al. 2005).

FAK is activated by autophosphorylation on tyrosine residue 397 in response to integrin ligation. This induces an interaction with Src that stabilizes the active conformation of Src, leading to increased catalytic activity. Subsequently, additional tyrosines on FAK are phosphorylated, resulting in full activation of both kinases (Schlaepfer et al. 1994; Calalb et al. 1995, 1996; Thomas et al. 1998). FAK represents an intersection point for GFR cross-talk, as the phosphorylation of FAK, and therefore its activation status, can be regulated by EGF (Kim and Kim 2008), and dephosphorylation of FAK in tumors that overexpress EGFR/HER2 has been proposed to be a contributing event in invasion and metastasis (Kim and Kim 2008). By using cells expressing a chimeric receptor consisting of the cytoplasmic domain of $\beta 1$ combined with the transmembrane and extracellular domains of the Tac subunit of human interleukin-2 receptor (Tac- $\beta 1)$, Src-mediated phosphorylation of specific substrates was shown to be dependent on FAK activation. In these cells, FAK autophosphorylation at Y397 is suppressed, but phosphorylation of Src is unaffected. Despite normal Src activation, phosphorylation of the downstream targets paxillin and p130Cas was strongly impaired (Berrier et al. 2008). In contrast, a study on the role of $\beta 1$ integrin in the development of mammary carcinomas in mice revealed that tumors lacking $\beta 1$ display defects in FAK but not in Src signaling, suggesting that these two molecules can function independently downstream from integrins (White et al. 2004). Whether this is true in other tumor types as well as in normal tissue requires further investigation.

The major signaling pathway downstream from the Src-FAK complex is the Ras-MEK-MAPK pathway, which is activated by integrated signals from integrins and growth factors. ERK2 phosphorylation downstream from integrins modulates both FA dynamics through myosin light chain kinase, as well as cell proliferation, cell cycle progression, and survival through regulating cyclin D1 and PI-3-kinase activity (Chen et al. 1996; Webb et al. 2004; Walker et al. 2005). Integrin signaling 
can influence MAPK activation on multiple levels. The Src-FAK complex activates PAK1, which in turn phosphorylates MEK1 on S298, which is critical for the assembly and localization of the activated signaling complex. Although growth factors can activate Ras independently of adhesion, activation of MEK1 by adhesionmediated signaling through Src-FAK is necessary for the signal to proceed to MAPK activation. Thus, MEK1 is a critical convergence point between growth factor and integrin signaling (Slack-Davis et al. 2003). Another intersection point of these two pathways occurs at the level of Raf1. In adherent cells, Raf1 is phosphorylated on a permissive S338, which is required for downstream activation of ERK. This phosphorylation is lost in suspended cells, rendering EGF unable to induce phosphorylation of ERK in nonadherent cells (Edin and Juliano 2005).

In summary, there are multiple ways by which the SrcFAK complex regulates ERK. This regulation seems to be cell-type-specific since deletion of FAK leads to proliferation defects in mammary epithelial cells (Nagy et al. 2007) and cardiomyocytes (Peng et al. 2006) but not in keratinocytes (Schober et al. 2007) or endothelial cells (Braren et al. 2006). These differences might be due to a tissue-specific compensation by the FAK family member Proline-rich tyrosine kinase 2 (Pyk2), or possible inhibitory effects of unphosphorylated FAK on cell proliferation (Pirone et al. 2006), which are relieved in the keratinocyte and endothelial cell models.

\section{Multiple roads to Akt activation}

FAK activation leads also to the recruitment of PI-3kinase to FAs. The resulting elevation of local PtdIns$3,4,5-\mathrm{P}_{3}$ serves to catalyze various signaling reactions, as well as to localize $\mathrm{PH}$ domain-containing proteins to the FAs. A central consequence of PI-3-kinase activation is activation of Akt, a ubiquitously expressed serine/threonine kinase that regulates integrin-mediated cell survival. Akt is activated by phosphorylation of Thr308 in the activation loop. This phosphorylation is carried out by PDK1, which is recruited to the plasma membrane by binding to PtdIns-3,4,5- $\mathrm{P}_{3}$ (Vanhaesebroeck and Alessi 2000). Akt is also phosphorylated at Ser473, which has been shown to regulate the specificity of Akt toward its substrates, and/or to stabilize its active conformation (Guertin et al. 2006; Ikenoue et al. 2008). Phosphorylation of Ser473 can be executed by mammalian target of rapamycin (mTOR) or ILK, depending on the cellular context. Genetic evidence suggests that mTOR is the predominant kinase under physiological conditions, whereas ILK could be required for Akt phosphorylation in certain tumor cells, particularly in cases where mTOR function is compromised (Guertin et al. 2006; Jacinto et al. 2006; Ikenoue et al. 2008; McDonald et al. 2008). However, mTOR is localized mainly to the endoplasmic reticulum and the Golgi, whereas Akt phosphorylation occurs primarily at the plasma membrane. Therefore it will be important to determine how integrin ligation can locally regulate Ser473 phosphorylation of Akt. One possibility is that this occurs indirectly; for example, through the phosphatase PP2A, which can dephosphorylate and thus inactivate Akt. The ability of $\beta 1$ integrin to directly bind and activate PP2A, which on the other hand is inactivated by mTOR, could provide a mechanism by which integrins locally switch on and off Akt signaling (Peterson et al. 1999; Ivaska et al. 2002; Pankov et al. 2003). Another possibility is that ILK acts as a scaffold to localize mTOR activity to FAs, as ILK was recently shown to bind rictor, an essential component of mTOR complex 2 (mTORC2) (McDonald et al. 2008). On the other hand it is possible that both mTOR and ILK act upstream of a yet-unidentified kinase that is responsible for the phosphorylation of Akt at Ser473. In addition to its role upstream of Akt, ILK represents another potential intersection point for GFR cross-talk as ILK is connected to GFRs via a Nck2PINCH-ILK interaction (Velyvis et al. 2003; Vaynberg et al. 2005). The relevant mTOR complex for Akt phosphorylation, mTORC2, is minimally affected by growth factor signaling (Woo et al. 2007), so other functions of ILK such as cytoskeleton reorganization may be the relevant targets of ILK-GFR cross-talk.

\section{Signaling through compartmentalization}

In addition to directly activating signaling pathways, integrins influence intracellular signaling by regulating plasma membrane order. Recent data suggest that integrin clustering induces the plasma membrane to organize into tightly packed, highly ordered lipid rafts locally in FAs (Gaus et al. 2006). A key property of these rafts is their ability to concentrate signaling proteins such as SFKs, H-Ras, and heterotrimeric G proteins, while selectively excluding proteins such as phosphatases. Even a small increase in local concentration of signaling molecules as a result of partitioning into a lipid raft can, through amplification, initiate signaling cascades (Simons and Toomre 2000). It has been shown that $\beta 1$ integrins depend on caveolae, a specific subclass of lipid rafts, to associate with Src and to activate FAK (Wei et al. 1999). This dependence on caveolae for Src-integrin association may explain why the Tac- $\beta 1$ hybrid, described above, is unable to support Src-mediated phosphorylation of FA-localized substrates. On the other hand, rapid internalization of rafts in response to changes in integrin ligand occupancy can effectively turn off entire signaling modules (del Pozo et al. 2004). GFRs are also constantly internalized, and this has a profound effect on the regulation of the signal: not merely as a mechanism to turn off the signal, but rather to regulate the kinetics of signaling as well as the activation profile of downstream kinases (Teis and Huber 2003).

In summary, integrin ligation leads to the activation of multiple signaling cascades with well characterized outputs. There are, however, multiple ways by which these cascades are activated and spatiotemporally regulated, both through the assembly of signaling modules as well as through regulation of plasma membrane order and endocytosis. The question of how these processes are regulated in three-dimensional environments as well as 
in vivo requires detailed exploration. The use of real time imaging to study the assembly, activity, and targeting of signaling complexes might provide valuable insights.

\section{Integrin-mediated control of insulin-like growth factor (IGF-1) receptor (IGF1R) signaling}

IGF-1 and IGF1R play important roles in growth and development; mutations in IGF-1 or IGF1R result in growth retardation in both mice and humans (Liu et al. 1993; Arends et al. 2002; Abuzzahab et al. 2003). Overexpression of IGF-1 in mice or administration of exogenous IGF-1 slows the age-related decline in skeletal muscle performance (Gonzalez et al. 2003; Moreno et al. 2006; Payne et al. 2006, 2007) and induces skeletal muscle hypertrophy in vitro (Musaro et al. 1999; Semsarian et al. 1999) and in vivo (Barton-Davis et al. 1998). IGF-1 expression or treatment also attenuates contraction defects and contraction-related injuries in a mouse model of Duchenne muscular dystrophy (Lynch et al. 2001; Schertzer et al. 2006, 2008; Gehrig et al. 2008), and speeds muscle regeneration following injury (Schertzer et al. 2006). Therefore, there is great interest in manipulating IGF1-mediated signaling pathways to treat muscular and aging-related disorders. Significant advances have been made in the last few years toward understanding the mechanism of IGF1R signaling, and reveal a significant degree of cross-talk with integrins that provides a good example of the intimate relationship between integrinand GFR-mediated signaling.

Skeletal muscle-specific deletion of ILK in mice results in a progressive muscular dystrophy characterized by abnormalities at the myotendinous junction (MTJ), increased fibrosis, and increased contraction-related injury (Wang et al. 2008). Normal muscles respond to exercise with increased phosphorylation of IGF1R and Akt, but both responses are attenuated in $\mathrm{ILK}^{-/-}$muscle, although Akt phosphorylation is not different in untrained muscle from both genotypes. Autocrine secretion of IGF-1 in muscles lacking ILK is greatly increased following exercise, presumably as a failed attempt to compensate for attenuated IGF1R activation. $\alpha 7 \beta 1$ integrin, which is normally located at the MTJ, is mislocalized in muscles lacking ILK, so it is possible that the attenuated IGF1R response in these mice results from an impaired interaction between $\beta 1$ integrin and IGF1R. An interaction between $\beta 1$ and IGF1R was previously reported to be important for full IGF1R activity in prostate cancer cells (Goel et al. 2004, 2005) and multiple myeloma (Tai et al. 2003). An interaction between $\beta 1$ and IGF1R is enhanced following IGF-1 treatment in mouse $\mathrm{C} 2 \mathrm{C} 12$ myoblast cells (Wang et al. 2008), implying that a functional interaction may also occur within untransformed skeletal muscle cells.

In human intestinal smooth muscle, IGF1R activity following IGF-1 treatment is augmented when cells are plated on fibronectin, and abrogated when cells were treated with the disintegrin echistatin, demonstrating that $\alpha \mathrm{v} \beta 3$-mediated binding to the RGD sequence within fibronectin is required for full IGF1R activity in these cells (Kuemmerle 2006). Likewise, treatment of porcine vascular smooth muscle cells (VSMCs) with vitronectin enhances IGF-1-mediated migration and proliferation, and increases pShc and pERK levels (Maile et al. 2006a,b). In this case the heparin-binding domain of vitronectin, which binds to the C-loop of $\beta 3$ and not to the RGDbinding domain, is sufficient for enhanced IGF1R activity. Mouse $\beta 3$ contains differences within the C-loop sequence that render mouse cells insensitive to vitronectin-enhanced IGF1R activity, in contrast to human and porcine $\beta 3$. Transfecting mouse VSMCs with human $\beta 3$ allows them to respond robustly to IGF-1 treatment when plated on vitronectin ( $\mathrm{Xi}$ et al. 2008). Together, these results demonstrate that fibronectin and vitronectin have different stimulatory effects on IGF1R signaling through the same integrin. Why the RGD sequence in vitronectin is not sufficient to augment IGF1R signaling via $\alpha \mathrm{v} \beta 3$, but the RGD sequence in fibronectin is sufficient, will require further study.

There are at least two mechanisms by which $\alpha \mathrm{v} \beta 3$ enhances IGF1R signaling. The first involves FAKdependent phosphorylation of IGF1R. FAK interacts with IGF1R in cell lysates; in $\mathrm{FAK}^{-1-}$ mouse embryonic fibroblasts, IGF1R phosphorylation is impaired in response to IGF-1, and IGF-1-dependent cell proliferation is blocked (Liu et al. 2008). The second mode of regulation involves the tyrosine phosphatase SHP-2 (Fig. 3A,B). In the absence of $\alpha \mathrm{V} \beta 3$ activation SHP-2 binds to and dephosphorylates IGF1R within minutes of IGF-1 stimulation, down-regulating IGF1R signaling (Maile and Clemmons $2002 \mathrm{a}, \mathrm{b})$. Ligation of $\alpha v \beta 3$ by fibronectin or vitronectin induces a $\beta 3-$ SHP-2 interaction, which sequesters the phosphatase and prolongs IGF1R signaling (Clemmons and Maile 2005). Interestingly, dephosphorylation of IGF1R in human pancreatic cancer cells is prevented by fibronectin, but not by vitronectin (Edderkaoui et al. 2007). SHP-2 is subsequently transferred from $\beta 3$ to SHP-2 substrate-1 (SHPS-1), a transmembrane protein that is phosphorylated by IGF1R in a manner dependent on integrin-associated protein, a binding partner of $\beta 3$ integrins (Maile et al. 2003, 2008). Finally, SHP-2 binding to SHPS- 1 induces the assembly of a signaling module to activate MAPK and PI-3-kinase signaling pathways (Clemmons and Maile 2005).

$\beta 1$ integrins are involved in an alternative signaling module centered on the scaffolding protein RACK (Fig. $3 \mathrm{C}, \mathrm{D})$. RACK is a 7-WD repeat-containing adaptor protein that connects IGF1R, PKC isoforms, and $\beta 1$ integrin in response to IGF-1 treatment in transformed cells (Hermanto et al. 2002). In unstimulated adherent fibroblasts IGF1R binds RACK1, which in turn binds the phosphatase PP2A. IGF-1 treatment induces the displacement of PP2A by $\beta 1$ and the recruitment to RACK of a signaling complex that ultimately results in increased cell migration toward IGF-1 (Kiely et al. 2005, 2006). Recent work using untransformed cardiomyocytes failed to detect a RACKIGF1R interaction in this cell type under any circumstances (O'Donovan et al. 2007). IGF-1 treatment caused the recruitment of Src and PKC isoforms to RACK in these cells; this does not occur when the RACK1-IGF1R in- 
teraction is disrupted in transformed cells (Kiely et al. 2005). Taken together, these data suggest that different RACK-mediated signaling complexes may assemble in untransformed and transformed cells, and possibly in a cell-type-specific manner. Further investigation is required to determine whether such differences could be exploited to control migration and metastasis in cancers that display aberrant IGF-1 signaling.

Work from two groups (Rusnati et al. 1997; Mori et al. 2008) has revealed an interaction between FGFs and $\alpha v \beta 3$ integrin. The binding sites on FGF1 for FGFR and integrin

A

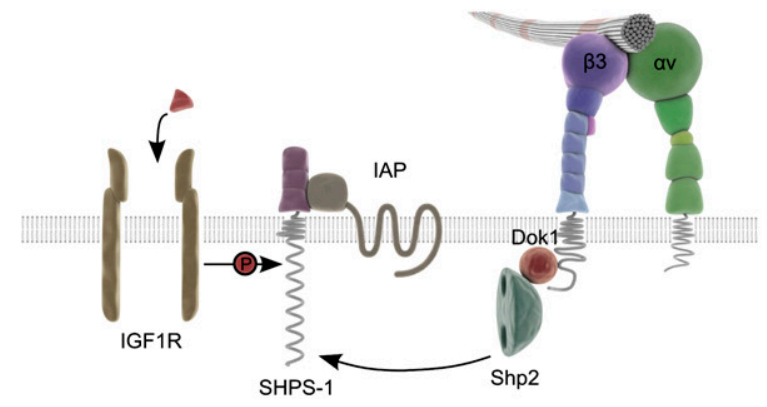

B

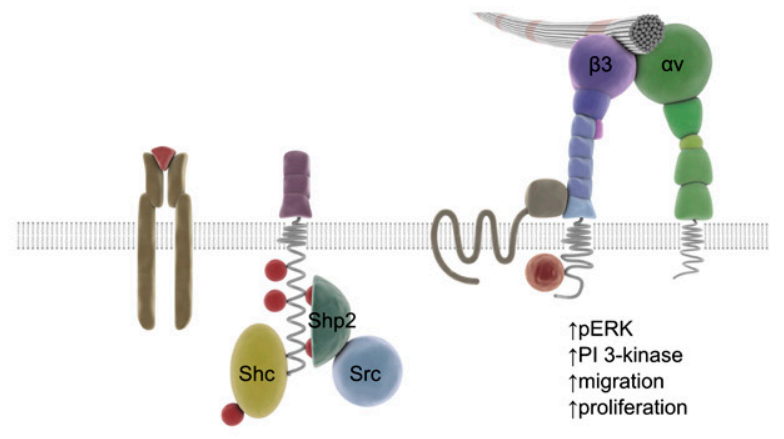

C

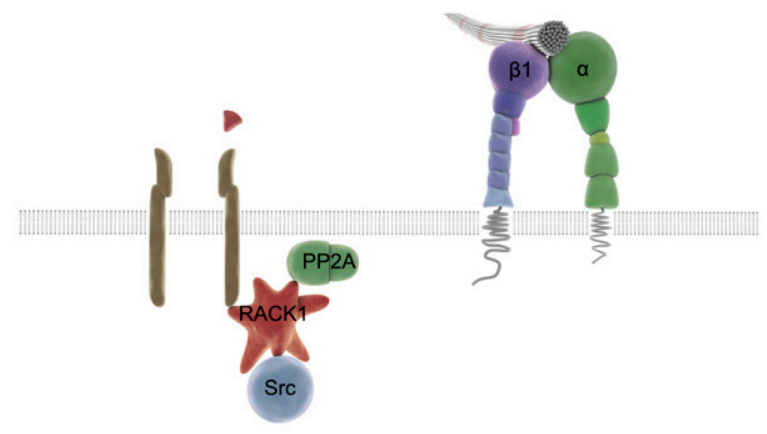

D

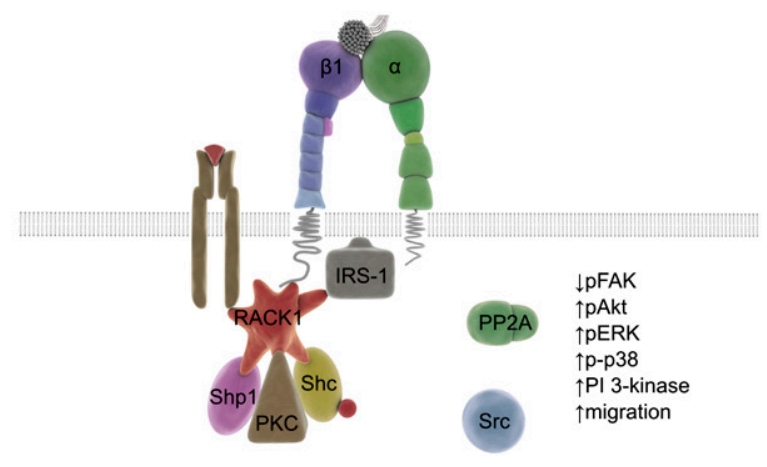

are distinct, and it has been proposed that FGF can bind to both FGFR and integrin in cis (Mori et al. 2008). A mutant form of FGF1 that does not bind to integrin retains early functions of FGF signaling, such as Akt and ERK phosphorylation, but later events such as DNA synthesis, cell proliferation, and migration are impaired. The integrinbinding site on FGF lies within the heparin-binding domain, resembling IGF1R regulation by vitronectin, at first glance. Future study will surely reveal whether mechanisms of integrin-FGFR cross-talk bear additional parallels to integrin-IGF1R cross-talk.

Taken together, these data demonstrate that cross-talk between GFRs and integrins occurs at multiple levels, from the sequestering and activation of growth factors by integrins (for example, TGF- $\beta$ ) (Sheppard 2005), to the regulation of transcriptional programs and PI-3-kinase activity that alter the composition of the integrin adhesome, and subsequent cellular behavior. GFR and integrin signaling operate both in conjunction with one another, as illustrated by integrin regulation of IGF1R signaling via SHP-1 and RACK discussed above, as well as in parallel pathways, illustrated by the observation that dual inhibition of FAK and IGFR1 is required to inhibit growth and induce apoptosis of pancreatic cancer cells and glioma cells in vitro (Liu et al. 2007, 2008). By manipulating the signaling pathways leading from integrins and GFRs and integrating them through cross-talk at every conceivable level, an appropriate response to complex extracellular inputs is assured.

\section{Perspectives}

Much of the work done to elucidate integrin inside-out signaling pathways has used tissue culture plastic as

Figure 3. Cross-talk between IGF-1 receptor and integrins. $(A, B)$ IGF1R and $\alpha \mathrm{v} \beta 3$ integrin cross-talk through a transmembrane mediator SHPS-1. In the absence of integrin activation the tyrosine phosphatase Shp2 rapidly binds and inactivates IGF1R, inhibiting downstream signaling. (A) Activated $\beta 3$ integrin binds to Shp2 via the adaptor molecule Dok1, and prevents Shp2 from interacting with IGF1R. (B) Activation of IGF1R leads to the phosphorylation of SHPS-1 in an IAP-dependent manner. Shp2 is transferred to phosphorylated SHPS-1, and this interaction is required for the subsequent recruitment and phosphorylation of the adaptor molecule Shc. Shp2 and Shc can bind to Src and Grb2 (not depicted), respectively, to promote downstream ERK and PI-3-kinase activation. $(C, D) \beta 1$ integrins and IGF1R cross-talk in transformed cells through a RACK1-mediated signaling complex. In the unstimulated state, RACK1 binds the phosphatase PP2A and Src, sequestering Src activity and enhancing PP2A activity. Activation of IGF1R leads to the displacement of PP2A by the $\beta 1$ tail, and the release of Src activity. A new signaling complex assembles onto RACK1, consisting of the phophatase Shp1, PKC, IRS-1, and Shc. Association of RACK with IGF1R is dependent on cell adhesion and RACK1 that cannot bind to IGF1R does not form this signaling complex. Molecules are not drawn to scale. (IGF1R) Insulin-like growth factor-1 receptor; (SHPS-1) Shp substrate 1 ; (IAP) integrin-associated protein; (Dok1) docking protein 1 ; (RACK1) receptor for activated C kinase 1 ; (PP2A) protein phosphatase type $2 \mathrm{~A}_{\text {; }}(\mathrm{PKC})$ protein kinase C; (IRS-1) insulin receptor substrate-1. 
a support, which is a rigid material not representative of the natural environment in which cells find themselves. Recent work has elegantly shown that matrix stiffness has profound effects on cell fate and behavior. Mesenchymal stem cells (MSCs) differentiate into neurons, myocytes, or osteoblasts in response to being cultured on collagen matrices of the appropriate physiological stiffness (Engler et al. 2006), and myotubes differentiate into striated muscle only on substrates approximating the stiffness of muscle (Engler et al. 2004). Matrix stiffness also has effects on cell migration, proliferation, and survival (Wells 2008). However, the mechanisms leading to such drastic changes in response to matrix stiffness are less well studied than the effects of soluble factors on these same properties. It is known that growth on soft substrates leads to smaller FAs containing less phosphotyrosine, and reduced cytoskeletal organization (Pelham and Wang 1997; Engler et al. 2006). Given the proof of principle from Engler et al. (2006) that matrix stiffness plays the predominant role in cell fate decisions in MSCs, more attention should be devoted to how changes in FA size and composition, and integrin-mediated changes in cytoskeletal organization, as well as other tension-dependent mechanisms such as stretch-activated cation channels (Copland and Post 2007), drive the genetic programs responsible for differentiation.

Many studies of integrin signaling have, for simplicity's sake, treated integrins as cell surface receptors functioning as isolated units but, as we are aware, integrin signaling is significantly influenced by GFRs. In addition, other transmembrane proteins such as tetraspanins and cell surface heparin sulfate proteoglycans such as syndecans have modulatory roles that affect integrin-mediated functions such as adhesion and migration. To gain a more thorough understanding of outside-in signaling it will be necessary to dissect the relative contributions of integrins and other cell surface receptors by revisiting what we think we know about integrin signaling and examining post-adhesion molecular events in the absence of functional modulators. For GFRs this can be achieved by expressing dimerization defective mutants or using inhibitory molecules, and for tetraspanins and syndecans this is being accomplished through the use of genetic knockout models and siRNA knockdown studies in cells. Taken together these investigations paint a picture of a complex, membrane-bound environmental sensor centered on integrins that parses extracellular physical and chemical cues into an appropriate intracellular response. Future studies will continue to build on and refine this current knowledge and will surely reveal many surprises in the years to come.

\section{Acknowledgments}

There is a vast amount of literature on integrin signaling, with more than 8500 articles cited on PubMed (and an additional 6500 articles if the alternative spelling "signalling" is used). We apologize to all those whose work could not be cited due to space restrictions, for not always citing all the primary literature, and for overlooking some important studies. We thank Arnoud Sonnenberg, Erik Danen, Su Hao Lo, and Staffan Johansson for helpful discussions during preparation of the manuscript and Max Iglesias for artwork. K.R.L. is recipient of a Marie Curie fellowship of the European Community 6th Framework Programme and S.A.W. is supported by the Sigrid Juselius Foundation, the Finnish Cultural Foundation and the Academy of Finland. The work of the Fässler laboratory is funded by the Max Planck Society.

\section{References}

Abuzzahab, M.J., Schneider, A., Goddard, A., Grigorescu, F., Lautier, C., Keller, E., Kiess, W., Klammt, J., Kratzsch, J., Osgood, D., et al. 2003. IGF-I receptor mutations resulting in intrauterine and postnatal growth retardation. N. Engl. J. Med. 349: 2211-2222.

Alexandrova, A.Y., Arnold, K., Schaub, S., Vasiliev, J.M., Meister, J.J., Bershadsky, A.D., and Verkhovsky, A.B. 2008. Comparative dynamics of retrograde actin flow and focal adhesions: Formation of nascent adhesions triggers transition from fast to slow flow. PLoS One 3: e3234. doi: 10.1371/journal.pone. 0003234.

Alon, R., Feigelson, S.W., Manevich, E., Rose, D.M., Schmitz, J., Overby, D.R., Winter, E., Grabovsky, V., Shinder, V., Matthews, B.D., et al. 2005. $\alpha 4 \beta 1$-dependent adhesion strengthening under mechanical strain is regulated by paxillin association with the $\alpha 4$-cytoplasmic domain. J. Cell Biol. 171: 1073-1084.

Arends, N., Johnston, L., Hokken-Koelega, A., van Duijn, C., de Ridder, M., Savage, M., and Clark, A. 2002. Polymorphism in the IGF-I gene: Clinical relevance for short children born small for gestational age (SGA). J. Clin. Endocrinol. Metab. 87: 2720-2724.

Arias-Salgado, E.G., Lizano, S., Sarkar, S., Brugge, J.S., Ginsberg, M.H., and Shattil, S.J. 2003. Src kinase activation by direct interaction with the integrin $\beta$ cytoplasmic domain. Proc. Natl. Acad. Sci. 100: 13298-13302.

Arias-Salgado, E.G., Lizano, S., Shattil, S.J., and Ginsberg, M.H. 2005. Specification of the direction of adhesive signaling by the integrin $\beta$ cytoplasmic domain. J. Biol. Chem. 280: 29699-29707.

Arthur, W.T. and Burridge, K. 2001. RhoA inactivation by p190RhoGAP regulates cell spreading and migration by promoting membrane protrusion and polarity. Mol. Biol. Cell 12: $2711-2720$.

Arthur, W.T., Petch, L.A., and Burridge, K. 2000. Integrin engagement suppresses RhoA activity via a c-Src-dependent mechanism. Curr. Biol. 10: 719-722.

Arthur, W.T., Quilliam, L.A., and Cooper, J.A. 2004. Rap1 promotes cell spreading by localizing rac guanine nucleotide exchange factors. I. Cell Biol. 167: 111-122.

Balaban, N.Q., Schwarz, U.S., Riveline, D., Goichberg, P., Tzur, G., Sabanay, I., Mahalu, D., Safran, S., Bershadsky, A., Addadi, L., et al. 2001. Force and focal adhesion assembly: A close relationship studied using elastic micropatterned substrates. Nat. Cell Biol. 3: 466-472.

Barton-Davis, E.R., Shoturma, D.I., Musaro, A., Rosenthal, N., and Sweeney, H.L. 1998. Viral mediated expression of insulinlike growth factor I blocks the aging-related loss of skeletal muscle function. Proc. Natl. Acad. Sci. 95: 1560315607.

Baum, P.D. and Garriga, G. 1997. Neuronal migrations and axon fasciculation are disrupted in ina-1 integrin mutants. Neuron 19: 51-62.

Bellis, S.L., Miller, J.T., and Turner, C.E. 1995. Characterization of tyrosine phosphorylation of paxillin in vitro by focal adhesion kinase. J. Biol. Chem. 270: 17437-17441. 
Benninger, Y., Thurnherr, T., Pereira, J.A., Krause, S., Wu, X., Chrostek-Grashoff, A., Herzog, D., Nave, K.A., Franklin, R.J., Meijer, D., et al. 2007. Essential and distinct roles for cdc42 and racl in the regulation of Schwann cell biology during peripheral nervous system development. J. Cell Biol. 177: 1051-1061.

Berrier, A.L., Jones, C.W., and LaFlamme, S.E. 2008. Tac- $\beta 1$ inhibits FAK activation and Src signaling. Biochem. Biophys. Res. Commun. 368: 62-67.

Boeri Erba, E., Bergatto, E., Cabodi, S., Silengo, L., Tarone, G., Defilippi, P., and Jensen, O.N. 2005. Systematic analysis of the epidermal growth factor receptor by mass spectrometry reveals stimulation-dependent multisite phosphorylation. Mol. Cell. Proteomics 4: 1107-1121.

Boerner, R.J., Kassel, D.B., Barker, S.C., Ellis, B., DeLacy, P., and Knight, W.B. 1996. Correlation of the phosphorylation states of pp60c-src with tyrosine kinase activity: The intramolecular pY530-SH2 complex retains significant activity if Y419 is phosphorylated. Biochemistry 35: 95199525.

Bouvard, D., Brakebusch, C., Gustafsson, E., Aszodi, A., Bengtsson, T., Berna, A., and Fässler, R. 2001. Functional consequences of integrin gene mutations in mice. Circ. Res. 89: 211-223.

Brabant, M.C. and Brower, D.L. 1993. PS2 integrin requirements in Drosophila embryo and wing morphogenesis. Dev. Biol. 157: 49-59.

Bradley, W.D., Hernandez, S.E., Settleman, J., and Koleske, A.J. 2006. Integrin signaling through Arg activates p190RhoGAP by promoting its binding to p120RasGAP and recruitment to the membrane. Mol. Biol. Cell 17: 4827-4836.

Braren, R., Hu, H., Kim, Y.H., Beggs, H.E., Reichardt, L.F., and Wang, R. 2006. Endothelial FAK is essential for vascular network stability, cell survival, and lamellipodial formation. J. Cell Biol. 172: 151-162.

Brower, D.L., Bunch, T.A., Mukai, L., Adamson, T.E., Wehrli, M., Lam, S., Friedlander, E., Roote, C.E., and Zusman, S. 1995. Nonequivalent requirements for PS1 and PS2 integrin at cell attachments in Drosophila: Genetic analysis of the $\alpha \mathrm{PS} 1$ integrin subunit. Development 121: 1311-1320.

Brown, N.H. 1994. Null mutations in the $\alpha P S 2$ and $\beta P S$ integrin subunit genes have distinct phenotypes. Development 120: 1221-1231.

Brown, N.H., Gregory, S.L., Rickoll, W.L., Fessler, L.I., Prout, M., White, R.A., and Fristrom, J.W. 2002. Talin is essential for integrin function in Drosophila. Dev. Cell 3: 569-579.

Brown, C.M., Hebert, B., Kolin, D.L., Zareno, J., Whitmore, L., Horwitz, A.R., and Wiseman, P.W. 2006. Probing the integrinactin linkage using high-resolution protein velocity mapping. J. Cell Sci. 119: 5204-5214.

Burbach, B.J., Medeiros, R.B., Mueller, K.L., and Shimizu, Y. 2007. T-cell receptor signaling to integrins. Immunol. Rev. 218: $65-81$.

Burbelo, P.D., Miyamoto, S., Utani, A., Brill, S., Yamada, K.M., Hall, A., and Yamada, Y. 1995. p190-B, a new member of the rho GAP family, and rho are induced to cluster after integrin cross-linking. J. Biol. Chem. 270: 30919-30926.

Butler, B., Gao, C., Mersich, A.T., and Blystone, S.D. 2006. Purified integrin adhesion complexes exhibit actin-polymerization activity. Curr. Biol. 16: 242-251.

Cai, D., Clayton, L.K., Smolyar, A., and Lerner, A. 1999. AND34, a novel p130Cas-binding thymic stromal cell protein regulated by adhesion and inflammatory cytokines. J. Immunol. 163: 2104-2112.

Calalb, M.B., Polte, T.R., and Hanks, S.K. 1995. Tyrosine phosphorylation of focal adhesion kinase at sites in the catalytic domain regulates kinase activity: A role for Src family kinases. Mol. Cell. Biol. 15: 954-963.

Calalb, M.B., Zhang, X., Polte, T.R., and Hanks, S.K. 1996. Focal adhesion kinase tyrosine-861 is a major site of phosphorylation by Src. Biochem. Biophys. Res. Commun. 228: 662-668.

Calderwood, D.A., Huttenlocher, A., Kiosses, W.B., Rose, D.M., Woodside, D.G., Schwartz, M.A., and Ginsberg, M.H. 2001. Increased filamin binding to $\beta$-integrin cytoplasmic domains inhibits cell migration. Nat. Cell Biol. 3: 1060-1068.

Calderwood, D.A., Fujioka, Y., de Pereda, J.M., Garcia-Alvarez, B., Nakamoto, T., Margolis, B., McGlade, C.J., Liddington, R.C., and Ginsberg, M.H. 2003. Integrin $\beta$ cytoplasmic domain interactions with phosphotyrosine-binding domains: A structural prototype for diversity in integrin signaling. Proc. Natl. Acad. Sci. 100: 2272-2277.

Cary, L.A., Han, D.C., Polte, T.R., Hanks, S.K., and Guan, J.L. 1998. Identification of p130Cas as a mediator of focal adhesion kinase-promoted cell migration. J. Cell Biol. 140: 211-221.

Chen, H.C. and Guan, J.L. 1994. Association of focal adhesion kinase with its potential substrate phosphatidylinositol 3-kinase. Proc. Natl. Acad. Sci. 91: 10148-10152.

Chen, H. and Lo, S.H. 2003. Regulation of tensin-promoted cell migration by its focal adhesion binding and Src homology domain 2. Biochem. J. 370: 1039-1045.

Chen, H.C., Appeddu, P.A., Isoda, H., and Guan, J.L. 1996. Phosphorylation of tyrosine 397 in focal adhesion kinase is required for binding phosphatidylinositol 3-kinase. J. Biol. Chem. 271: 26329-26334.

Chen, H., Duncan, I.C., Bozorgchami, H., and Lo, S.H. 2002. Tensin 1 and a previously undocumented family member, tensin2, positively regulate cell migration. Proc. Natl. Acad. Sci. 99: 733-738.

Chiang, M.K., Liao, Y.C., Kuwabara, Y., and Lo, S.H. 2005. Inactivation of tensin 3 in mice results in growth retardation and postnatal lethality. Dev. Biol. 279: 368-377.

Choi, C.K., Vicente-Manzanares, M., Zareno, J., Whitmore, L.A., Mogilner, A., and Horwitz, A.R. 2008. Actin and $\alpha$-actinin orchestrate the assembly and maturation of nascent adhesions in a myosin II motor-independent manner. Nat. Cell Biol. 10: 1039-1050.

Clemmons, D.R. and Maile, L.A. 2005. Interaction between insulin-like growth factor-I receptor and $\alpha \mathrm{V} \beta 3$ integrin linked signaling pathways: Cellular responses to changes in multiple signaling inputs. Mol. Endocrinol. 19: 1-11.

Copland, I.B. and Post, M. 2007. Stretch-activated signaling pathways responsible for early response gene expression in fetal lung epithelial cells. J. Cell. Physiol. 210: 133-143.

Corgan, A.M., Singleton, C., Santoso, C.B., and Greenwood, J.A. 2004. Phosphoinositides differentially regulate $\alpha$-actinin flexibility and function. Biochem. J. 378: 1067-1072.

Cox, E.A., Tuskey, C., and Hardin, J. 2004. Cell adhesion receptors in C. elegans. J. Cell Sci. 117: 1867-1870.

Cram, E.J., Clark, S.G., and Schwarzbauer, J.E. 2003. Talin lossof-function uncovers roles in cell contractility and migration in C. elegans. J. Cell Sci. 116: 3871-3878.

Cramer, L.P., Siebert, M., and Mitchison, T.J. 1997. Identification of novel graded polarity actin filament bundles in locomoting heart fibroblasts: Implications for the generation of motile force. J. Cell Biol. 136: 1287-1305.

Critchley, D.R. and Gingras, A.R. 2008. Talin at a glance. J. Cell Sci. 121: 1345-1347.

Cui, W., Hu, S.X., Tang, Z.Y., and Hu, K.Q. 2008. In-vivo effects and mechanisms of celecoxib-reduced growth of cyclooxygenase-2 (COX-2)-expressing versus COX-2-deleted human HCC xenografts in nude mice. Anticancer Drugs 19: 891-897. 
Czuchra, A., Wu, X., Meyer, H., van Hengel, J., Schroeder, T., Geffers, R., Rottner, K., and Brakebusch, C. 2005. Cdc42 is not essential for filopodium formation, directed migration, cell polarization, and mitosis in fibroblastoid cells. Mol. Biol. Cell 16: 4473-4484.

Dai, C., Stolz, D.B., Bastacky, S.I., St-Arnaud, R., Wu, C., Dedhar, S., and Liu, Y. 2006. Essential role of integrinlinked kinase in podocyte biology: Bridging the integrin and slit diaphragm signaling. J. Am. Soc. Nephrol. 17: 21642175.

Dandapani, S.V., Sugimoto, H., Matthews, B.D., Kolb, R.J., Sinha, S., Gerszten, R.E., Zhou, J., Ingber, D.E., Kalluri, R., and Pollak, M.R. 2007. $\alpha$-actinin-4 is required for normal podocyte adhesion. J. Biol. Chem. 282: 467-477.

Danen, E.H., Sonneveld, P., Brakebusch, C., Fässler, R., and Sonnenberg, A. 2002. The fibronectin-binding integrins $\alpha 5 \beta 1$ and $\alpha v \beta 3$ differentially modulate RhoA-GTP loading, organization of cell matrix adhesions, and fibronectin fibrillogenesis. J. Cell Biol. 159: 1071-1086.

Defilippi, P., Di Stefano, P., and Cabodi, S. 2006. p130Cas: A versatile scaffold in signaling networks. Trends Cell Biol. 16: 257-263.

Degani, S., Balzac, F., Brancaccio, M., Guazzone, S., Retta, S.F., Silengo, L., Eva, A., and Tarone, G. 2002. The integrin cytoplasmic domain-associated protein ICAP-1 binds and regulates rho family GTPases during cell spreading. I. Cell Biol. 156: 377-387.

del Pozo, M.A., Alderson, N.B., Kiosses, W.B., Chiang, H.H., Anderson, R.G., and Schwartz, M.A. 2004. Integrins regulate Rac targeting by internalization of membrane domains. Science 303: 839-842.

DeMali, K.A., Barlow, C.A., and Burridge, K. 2002. Recruitment of the Arp $2 / 3$ complex to vinculin: Coupling membrane protrusion to matrix adhesion. J. Cell Biol. 159: 881-891.

den Hertog, J., Pals, C.E., Peppelenbosch, M.P., Tertoolen, L.G., de Laat, S.W., and Kruijer, W. 1993. Receptor protein tyrosine phosphatase $\alpha$ activates pp60c-src and is involved in neuronal differentiation. EMBO J. 12: 3789-3798.

de Virgilio, M., Kiosses, W.B., and Shattil, S.J. 2004. Proximal, selective, and dynamic interactions between integrin $\alpha \mathrm{II} \beta 3$ and protein tyrosine kinases in living cells. J. Cell Biol. 165: 305-311.

Dho, S.E., French, M.B., Woods, S.A., and McGlade, C.J. 1999. Characterization of four mammalian numb protein isoforms. Identification of cytoplasmic and membrane-associated variants of the phosphotyrosine binding domain. J. Biol. Chem. 274: 33097-33104.

Digman, M.A., Brown, C.M., Horwitz, A.R., Mantulin, W.W., and Gratton, E. 2008. Paxillin dynamics measured during adhesion assembly and disassembly by correlation spectroscopy. Biophys. J. 94: 2819-2831.

Di Paolo, G., Pellegrini, L., Letinic, K., Cestra, G., Zoncu, R., Voronov, S., Chang, S., Guo, J., Wenk, M.R., and De Camilli, P. 2002. Recruitment and regulation of phosphatidylinositol phosphate kinase type $1 \gamma$ by the FERM domain of talin. Nature 420: 85-89.

Dubash, A.D., Wennerberg, K., Garcia-Mata, R., Menold, M.M., Arthur, W.T., and Burridge, K. 2007. A novel role for Lsc/ p115 RhoGEF and LARG in regulating RhoA activity downstream of adhesion to fibronectin. J. Cell Sci. 120: 3989-3998.

Edderkaoui, M., Hong, P., Lee, J.K., Pandol, S.J., and Gukovskaya, A.S. 2007. Insulin-like growth factor-I receptor mediates the prosurvival effect of fibronectin. J. Biol. Chem. 282: 2664626655

Edin, M.L. and Juliano, R.L. 2005. Raf-1 serine 338 phosphorylation plays a key role in adhesion-dependent activation of extracellular signal-regulated kinase by epidermal growth factor. Mol. Cell. Biol. 25: 4466-4475.

Engler, A.J., Griffin, M.A., Sen, S., Bonnemann, C.G., Sweeney, H.L., and Discher, D.E. 2004. Myotubes differentiate optimally on substrates with tissue-like stiffness: Pathological implications for soft or stiff microenvironments. J. Cell Biol. 166: 877-887.

Engler, A.J., Sen, S., Sweeney, H.L., and Discher, D.E. 2006. Matrix elasticity directs stem cell lineage specification. Cell 126: 677-689.

Etienne-Manneville, S. and Hall, A. 2001. Integrin-mediated activation of $\mathrm{Cdc} 42$ controls cell polarity in migrating astrocytes through PKCzeta. Cell 106: 489-498.

Even-Ram, S., Artym, V., and Yamada, K.M. 2006. Matrix control of stem cell fate. Cell 126: 645-647.

Even-Ram, S., Doyle, A.D., Conti, M.A., Matsumoto, K., Adelstein, R.S., and Yamada, K.M. 2007. Myosin IIA regulates cell motility and actomyosin-microtubule crosstalk. Nat. Cell Biol. 9: 299-309.

Fagerholm, S.C., Hilden, T.J., Nurmi, S.M., and Gahmberg, C.G. 2005. Specific integrin $\alpha$ and $\beta$ chain phosphorylations regulate LFA-1 activation through affinity-dependent and -independent mechanisms. J. Cell Biol. 171: 705-715.

Ferrell J.E. and Martin, G.S. 1989. Tyrosine-specific protein phosphorylation is regulated by glycoprotein IIb-IIIa in platelets. Proc. Natl. Acad. Sci. 86: 2234-2238.

Filipenko, N.R., Attwell, S., Roskelley, C., and Dedhar, S. 2005. Integrin-linked kinase activity regulates Rac- and Cdc42mediated actin cytoskeleton reorganization via $\alpha$-PIX. Oncogene 24: 5837-5849.

Fillingham, I., Gingras, A.R., Papagrigoriou, E., Patel, B., Emsley, J., Critchley, D.R., Roberts, G.C., and Barsukov, I.L. 2005. A vinculin binding domain from the talin rod unfolds to form a complex with the vinculin head. Structure 13: 65-74.

Flevaris, P., Stojanovic, A., Gong, H., Chishti, A., Welch, E., and Du, X. 2007. A molecular switch that controls cell spreading and retraction. J. Cell Biol. 179: 553-565.

Freed, E., Gailit, J., van der Geer, P., Ruoslahti, E., and Hunter, T. 1989. A novel integrin $\beta$ subunit is associated with the vitronectin receptor $\alpha$ subunit $(\alpha \mathrm{v})$ in a human osteosarcoma cell line and is a substrate for protein kinase C. $E M B O ~ J .8$ : 2955-2965.

Fukata, M., Nakagawa, M., and Kaibuchi, K. 2003. Roles of Rhofamily GTPases in cell polarisation and directional migration. Curr. Opin. Cell Biol. 15: 590-597.

Fyrberg, C., Ketchum, A., Ball, E., and Fyrberg, E. 1998. Characterization of lethal Drosophila melanogaster $\alpha$-actinin mutants. Biochem. Genet. 36: 299-310.

Galbraith, C.G., Skalak, R., and Chien, S. 1998. Shear stress induces spatial reorganization of the endothelial cell cytoskeleton. Cell Motil. Cytoskeleton 40: 317-330.

Galbraith, C.G., Yamada, K.M., and Sheetz, M.P. 2002. The relationship between force and focal complex development. J. Cell Biol. 159: 695-705.

Gallant, N.D., Michael, K.E., and Garcia, A.J. 2005. Cell adhesion strengthening: Contributions of adhesive area, integrin binding, and focal adhesion assembly. Mol. Biol. Cell 16: 4329-4340.

Gao, C., Schaefer, E., Lakkis, M., and Blystone, S.D. 2005. $\beta 3$ tyrosine phosphorylation and $\alpha \mathrm{v} \beta 3$-mediated adhesion are required for Vav1 association and rho activation in leukocytes. J. Biol. Chem. 280: 15422-15429.

Garvalov, B.K., Flynn, K.C., Neukirchen, D., Meyn, L., Teusch, N., Wu, X., Brakebusch, C., Bamburg, J.R., and Bradke, F. 2007. Cdc42 regulates cofilin during the establishment of neuronal polarity. J. Neurosci. 27: 13117-13129. 
Gaus, K., Le Lay, S., Balasubramanian, N., and Schwartz, M.A. 2006. Integrin-mediated adhesion regulates membrane order. I. Cell Biol. 174: 725-734.

Gehrig, S.M., Ryall, J.G., Schertzer, J.D., and Lynch, G.S. 2008. IGF-I analogue protects muscles of dystrophic $\mathrm{mdx}$ mice from contraction-mediated damage. Exp. Physiol. 93: 11901198.

Geiger, B., Bershadsky, A., Pankov, R., and Yamada, K.M. 2001. Transmembrane crosstalk between the extracellular matrixcytoskeleton crosstalk. Nat. Rev. Mol. Cell Biol. 2: 793-805.

Gettner, S.N., Kenyon, C., and Reichardt, L.F. 1995. Characterization of $\beta$ pat- 3 heterodimers, a family of essential integrin receptors in C. elegans. J. Cell Biol. 129: 1127-1141.

Giannone, G., Dubin-Thaler, B.J., Rossier, O., Cai, Y., Chaga, O., Jiang, G., Beaver, W., Dobereiner, H.G., Freund, Y., Borisy, G., et al. 2007. Lamellipodial actin mechanically links myosin activity with adhesion-site formation. Cell 128: 561-575.

Gingras, A.R., Ziegler, W.H., Frank, R., Barsukov, I.L., Roberts, G.C., Critchley, D.R., and Emsley, J. 2005. Mapping and consensus sequence identification for multiple vinculin binding sites within the talin rod. J. Biol. Chem. 280: 37217-37224.

Goel, H.L., Fornaro, M., Moro, L., Teider, N., Rhim, J.S., King, M., and Languino, L.R. 2004. Selective modulation of type 1 insulin-like growth factor receptor signaling and functions by $\beta 1$ integrins. J. Cell Biol. 166: 407-418.

Goel, H.L., Breen, M., Zhang, J., Das, I., Aznavoorian-Cheshire, S., Greenberg, N.M., Elgavish, A., and Languino, L.R. 2005 $\beta 1 \mathrm{~A}$ integrin expression is required for type 1 insulin-like growth factor receptor mitogenic and transforming activities and localization to focal contacts. Cancer Res. 65: 66926700.

Goksoy, E., Ma, Y.Q., Wang, X., Kong, X., Perera, D., Plow, E.F., and Qin, J. 2008. Structural basis for the autoinhibition of talin in regulating integrin activation. Mol. Cell 31: 124133.

Golden, A., Brugge, J.S., and Shattil, S.J. 1990. Role of platelet membrane glycoprotein IIb-IIIa in agonist-induced tyrosine phosphorylation of platelet proteins. J. Cell Biol. 111: $3117-$ 3127.

Gonzalez, E., Messi, M.L., Zheng, Z., and Delbono, O. 2003. Insulin-like growth factor-1 prevents age-related decrease in specific force and intracellular $\mathrm{Ca}^{2+}$ in single intact muscle fibres from transgenic mice. J. Physiol. 552: 833-844.

Green, C.E., Pearson, D.N., Camphausen, R.T., Staunton, D.E., and Simon, S.I. 2004. Shear-dependent capping of L-selectin and P-selectin glycoprotein ligand 1 by E-selectin signals activation of high-avidity $\beta 2$-integrin on neutrophils. $J$. Immunol. 172: 7780-7790.

Greenwood, J.A., Theibert, A.B., Prestwich, G.D., and MurphyUllrich, J.E. 2000. Restructuring of focal adhesion plaques by PI 3-kinase. Regulation by PtdIns $(3,4,5)$-p $(3)$ binding to $\alpha$-actinin. J. Cell Biol. 150: 627-642.

Grimsley, C.M., Kinchen, J.M., Tosello-Trampont, A.C., Brugnera, E., Haney, L.B., Lu, M., Chen, Q., Klingele, D., Hengartner, M.O., and Ravichandran, K.S. 2004. Dock180 and ELMO1 proteins cooperate to promote evolutionarily conserved racdependent cell migration. J. Biol. Chem. 279: 6087-6097.

Guertin, D.A., Stevens, D.M., Thoreen, C.C., Burds, A.A., Kalaany, N.Y., Moffat, J., Brown, M., Fitzgerald, K.J., and Sabatini, D.M. 2006. Ablation in mice of the mTORC components raptor, rictor, or mLST8 reveals that mTORC2 is required for signaling to Akt-FOXO and $\mathrm{PKC} \alpha$, but not S6K1. Dev. Cell 11: 859-871.

Guillou, H., Depraz-Depland, A., Planus, E., Vianay, B., Chaussy, J., Grichine, A., Albiges-Rizo, C., and Block, M.R. 2008.
Lamellipodia nucleation by filopodia depends on integrin occupancy and downstream Rac1 signaling. Exp. Cell Res. 314: 478-488.

Ha, V.L., Bharti, S., Inoue, H., Vass, W.C., Campa, F., Nie, Z., de Gramont, A., Ward, Y., and Randazzo, P.A. 2008. ASAP3 is a focal adhesion-associated arf GAP that functions in cell migration and invasion. J. Biol. Chem. 283: 1491514926.

Han, D.C., Rodriguez, L.G., and Guan, J.L. 2001. Identification of a novel interaction between integrin $\beta 1$ and $14-3-3 \beta$. Oncogene 20: 346-357.

Hayakawa, K., Sato, N., and Obinata, T. 2001. Dynamic reorientation of cultured cells and stress fibers under mechanical stress from periodic stretching. Exp. Cell Res. 268: 104-114.

Hayashi, I., Vuori, K., and Liddington, R.C. 2002. The focal adhesion targeting (FAT) region of focal adhesion kinase is a four-helix bundle that binds paxillin. Nat. Struct. Biol. 9: 101-106.

Hermanto, U., Zong, C.S., Li, W., and Wang, L.H. 2002. RACK1, an insulin-like growth factor I (IGF-I) receptor-interacting protein, modulates IGF-I-dependent integrin signaling and promotes cell spreading and contact with extracellular matrix. Mol. Cell. Biol. 22: 2345-2365.

Hibbs, M.L., Jakes, S., Stacker, S.A., Wallace, R.W., and Springer, T.A. 1991. The cytoplasmic domain of the integrin lymphocyte function-associated antigen $1 \beta$ subunit: Sites required for binding to intercellular adhesion molecule 1 and the phorbol ester-stimulated phosphorylation site. I. Exp. Med. 174: $1227-1238$.

Hildebrand, J.D., Taylor, J.M., and Parsons, J.T. 1996. An SH3 domain-containing GTPase-activating protein for rho and Cdc42 associates with focal adhesion kinase. Mol. Cell. Biol. 16: $3169-3178$.

Hotulainen, P. and Lappalainen, P. 2006. Stress fibers are generated by two distinct actin assembly mechanisms in motile cells. J. Cell Biol. 173: 383-394.

$\mathrm{Hu}$, K., Ji, L., Applegate, K.T., Danuser, G., and WatermanStorer, C.M. 2007. Differential transmission of actin motion within focal adhesions. Science 315: 111-115.

Humphries, J.D., Byron, A., and Humphries, M.J. 2006. Integrin ligands at a glance. J. Cell Sci. 119: 3901-3903.

Humphries, J.D., Wang, P., Streuli, C., Geiger, B., Humphries, M.J., and Ballestrem, C. 2007. Vinculin controls focal adhesion formation by direct interactions with talin and actin. $J$. Cell Biol. 179: 1043-1057.

Hynes, R.O. 2002. Integrins: Bidirectional, allosteric signaling machines. Cell 110: 673-687.

Ikenoue, T., Inoki, K., Yang, Q., Zhou, X., and Guan, K.L. 2008. Essential function of TORC2 in PKC and Akt turn motif phosphorylation, maturation and signalling. EMBO J. 27: 1919-1931.

Ilic, D., Furuta, Y., Kanazawa, S., Takeda, N., Sobue, K., Nakatsuji, N., Nomura, S., Fujimoto, J., Okada, M., and Yamamoto, T. 1995. Reduced cell motility and enhanced focal adhesion contact formation in cells from FAK-deficient mice. Nature 377: 539-544.

Ingber, D.E. 2006. Mechanical control of tissue morphogenesis during embryological development. Int. J. Dev. Biol. 50: 255266.

Ivaska, J., Nissinen, L., Immonen, N., Eriksson, J.E., Kahari, V.M., and Heino, J. 2002. Integrin $\alpha 2 \beta 1$ promotes activation of protein phosphatase $2 \mathrm{~A}$ and dephosphorylation of Akt and glycogen synthase kinase 3ß. Mol. Cell. Biol. 22: 1352-1359.

Izaguirre, G., Aguirre, L., Hu, Y.P., Lee, H.Y., Schlaepfer, D.D., Aneskievich, B.J., and Haimovich, B. 2001. The cytoskeletal/ non-muscle isoform of $\alpha$-actinin is phosphorylated on its 
actin-binding domain by the focal adhesion kinase. J. Biol. Chem. 276: 28676-28685.

Jacinto, E., Facchinetti, V., Liu, D., Soto, N., Wei, S., Jung, S.Y., Huang, Q., Qin, J., and Su, B. 2006. SIN1/MIP1 maintains rictor-mTOR complex integrity and regulates Akt phosphorylation and substrate specificity. Cell 127: 125-137.

Jaffe, A.B. and Hall, A. 2005. Rho GTPases: Biochemistry and biology. Annu. Rev. Cell Dev. Biol. 21: 247-269.

Jiang, G., Giannone, G., Critchley, D.R., Fukumoto, E., and Sheetz, M.P. 2003. Two-piconewton slip bond between fibronectin and the cytoskeleton depends on talin. Nature 424: 334-337.

Kaplan, J.M., Kim, S.H., North, K.N., Rennke, H., Correia, L.A., Tong, H.Q., Mathis, B.J., Rodriguez-Perez, J.C., Allen, P.G., Beggs, A.H., et al. 2000. Mutations in ACTN4, encoding $\alpha$-actinin-4, cause familial focal segmental glomerulosclerosis. Nat. Genet. 24: 251-256.

Kawai, K., Kiyota, M., Seike, J., Deki, Y., and Yagisawa, H. 2007. START-GAP3/DLC3 is a GAP for RhoA and Cdc42 and is localized in focal adhesions regulating cell morphology. Biochem. Biophys. Res. Commun. 364: 783-789.

Kharbanda, S., Saleem, A., Yuan, Z., Emoto, Y., Prasad, K.V., and Kufe, D. 1995. Stimulation of human monocytes with macrophage colony-stimulating factor induces a Grb2-mediated association of the focal adhesion kinase pp125FAK and dynamin. Proc. Natl. Acad. Sci. 92: 6132-6136.

Kiely, P.A., Leahy, M., O'Gorman, D., and O'Connor, R. 2005. RACK1-mediated integration of adhesion and insulinlike growth factor I (IGF-I) signaling and cell migration are defective in cells expressing an IGF-I receptor mutated at tyrosines 1250 and 1251. J. Biol. Chem. 280: 76247633.

Kiely, P.A., O'Gorman, D., Luong, K., Ron, D., and O'Connor, R. 2006. Insulin-like growth factor I controls a mutually exclusive association of RACK1 with protein phosphatase $2 \mathrm{~A}$ and $\beta 1$ integrin to promote cell migration. Mol. Cell. Biol. 26: 4041-4051.

Kim, S.H. and Kim, S.H. 2008. Antagonistic effect of EGF on FAK phosphorylation/dephosphorylation in a cell. Cell Biochem. Funct. 26: 539-547.

Kiosses, W.B., Shattil, S.J., Pampori, N., and Schwartz, M.A. 2001. Rac recruits high-affinity integrin $\alpha v \beta 3$ to lamellipodia in endothelial cell migration. Nat. Cell Biol. 3: 316-320.

Kirk, R.I., Sanderson, M.R., and Lerea, K.M. 2000. Threonine phosphorylation of the $\beta 3$ integrin cytoplasmic tail, at a site recognized by PDK1 and Akt/PKB in vitro, regulates Shc binding. J. Biol. Chem. 275: 30901-30906.

Kiyokawa, E., Hashimoto, Y., Kobayashi, S., Sugimura, H., Kurata, T., and Matsuda, M. 1998. Activation of Rac1 by a Crk SH3-binding protein, DOCK180. Genes \& Dev. 12: 3331-3336.

Klemke, R.L., Leng, J., Molander, R., Brooks, P.C., Vuori, K., and Cheresh, D.A. 1998. CAS/Crk coupling serves as a 'molecular switch' for induction of cell migration. J. Cell Biol. 140: 961972.

Kondo, A., Hashimoto, S., Yano, H., Nagayama, K., Mazaki, Y., and Sabe, H. 2000. A new paxillin-binding protein, PAG3/ $\mathrm{Pap} \alpha / \mathrm{KIAA0400}$, bearing an ADP-ribosylation factor GTPaseactivating protein activity, is involved in paxillin recruitment to focal adhesions and cell migration. Mol. Biol. Cell 11: $1315-1327$

Kos, C.H., Le, T.C., Sinha, S., Henderson, J.M., Kim, S.H., Sugimoto, H., Kalluri, R., Gerszten, R.E., and Pollak, M.R. 2003. Mice deficient in $\alpha$-actinin-4 have severe glomerular disease. J. Clin. Invest. 111: 1683-1690.
Kuemmerle, J.F. 2006. Occupation of $\alpha v \beta 3$-integrin by endogenous ligands modulates IGF-I receptor activation and proliferation of human intestinal smooth muscle. Am. J. Physiol. Gastrointest. Liver Physiol. 290: G1194-G1202. doi: 10. 1152/ajpgi.00345.2005.

LaLonde, D.P., Grubinger, M., Lamarche-Vane, N., and Turner, C.E. 2006. CdGAP associates with actopaxin to regulate integrin-dependent changes in cell morphology and motility. Curr. Biol. 16: 1375-1385.

Laukaitis, C.M., Webb, D.J., Donais, K., and Horwitz, A.F. 2001. Differential dynamics of $\alpha 5$ integrin, paxillin, and $\alpha$-actinin during formation and disassembly of adhesions in migrating cells. I. Cell Biol. 153: 1427-1440.

Lavelin, I. and Geiger, B. 2005. Characterization of a novel GTPase-activating protein associated with focal adhesions and the actin cytoskeleton. J. Biol. Chem. 280: 7178-7185.

Lee, S.E., Kamm, R.D., and Mofrad, M.R. 2007. Force-induced activation of talin and its possible role in focal adhesion mechanotransduction. J. Biomech. 40: 2096-2106.

Legate, K.R. and Fässler, R. 2009. Mechanisms that regulate adaptor binding to $\beta$-integrin cytoplasmic tails. J. Cell Sci. 122: $187-198$.

Legate, K.R., Montanez, E., Kudlacek, O., and Fässler, R. 2006. ILK, PINCH and parvin: The tIPP of integrin signalling. Nat. Rev. Mol. Cell Biol. 7: 20-31.

Lehtonen, S., Ryan, J.J., Kudlicka, K., Iino, N., Zhou, H., and Farquhar, M.G. 2005. Cell junction-associated proteins IQGAP1, MAGI-2, CASK, spectrins, and $\alpha$-actinin are components of the nephrin multiprotein complex. Proc. Natl. Acad. Sci. 102: 9814-9819.

Leone, M., Yu, E.C., Liddington, R.C., Pasquale, E.B., and Pellecchia, M. 2008. The PTB domain of tensin: NMR solution structure and phosphoinositides binding studies. Biopolymers 89: 86-92.

Lerea, K.M., Venjara, A.Y., Olson, S.C., and Kelly, M.R. 2007. Threonine phosphorylation of integrin $\beta 3$ in calyculin A-treated platelets is selectively sensitive to $5^{\prime}$-iodotubercidin. Biochim. Biophys. Acta 1773: 185-191.

Liang, F., Lee, S.Y., Liang, J., Lawrence, D.S., and Zhang, Z.Y. 2005. The role of protein-tyrosine phosphatase $1 \mathrm{~B}$ in integrin signaling. J. Biol. Chem. 280: 24857-24863.

Liao, Y.C., Si, L., deVere White, R.W., and Lo, S.H. 2007. The phosphotyrosine-independent interaction of DLC-1 and the $\mathrm{SH} 2$ domain of cten regulates focal adhesion localization and growth suppression activity of DLC-1. J. Cell Biol. 176: 43-49.

Lim, J., Wiedemann, A., Tzircotis, G., Monkley, S.J., Critchley, D.R., and Caron, E. 2007. An essential role for talin during

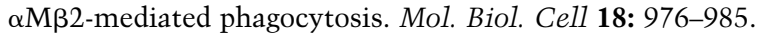

Ling, K., Doughman, R.L., Firestone, A.J., Bunce, M.W., and Anderson, R.A. 2002. Type I $\gamma$ phosphatidylinositol phosphate kinase targets and regulates focal adhesions. Nature 420: 89-93.

Liu, J.P., Baker, J., Perkins, A.S., Robertson, E.J., and Efstratiadis, A. 1993. Mice carrying null mutations of the genes encoding insulin-like growth factor I (Igf-1) and type 1 IGF receptor (Igf1r). Cell 75: 59-72.

Liu, G., Guibao, C.D., and Zheng, J. 2002. Structural insight into the mechanisms of targeting and signaling of focal adhesion kinase. Mol. Cell. Biol. 22: 2751-2760.

Liu, Y., Loijens, J.C., Martin, K.H., Karginov, A.V., and Parsons, J.T. 2002. The association of ASAP1, an ADP ribosylation factor-GTPase activating protein, with focal adhesion kinase contributes to the process of focal adhesion assembly. Mol. Biol. Cell 13: 2147-2156. 
Liu, T.J., LaFortune, T., Honda, T., Ohmori, O., Hatakeyama, S., Meyer, T., Jackson, D., de Groot, J., and Yung, W.K. 2007. Inhibition of both focal adhesion kinase and insulin-like growth factor-I receptor kinase suppresses glioma proliferation in vitro and in vivo. Mol. Cancer Ther. 6: 1357-1367.

Liu, W., Bloom, D.A., Cance, W.G., Kurenova, E.V., Golubovskaya, V.M., and Hochwald, S.N. 2008. FAK and IGF-IR interact to provide survival signals in human pancreatic adenocarcinoma cells. Carcinogenesis 29: 1096-1107.

Lo, S.H. and Lo, T.B. 2002. Cten, a COOH-terminal tensin-like protein with prostate restricted expression, is down-regulated in prostate cancer. Cancer Res. 62: 4217-4221.

Lo, S.H., Janmey, P.A., Hartwig, J.H., and Chen, L.B. 1994. Interactions of tensin with actin and identification of its three distinct actin-binding domains. J. Cell Biol. 125: 10671075.

Luo, B.H., Carman, C.V., and Springer, T.A. 2007. Structural basis of integrin regulation and signaling. Annu. Rev. Immunol. 25: 619-647.

Lynch, G.S., Cuffe, S.A., Plant, D.R., and Gregorevic, P. 2001. IGF-I treatment improves the functional properties of fastand slow-twitch skeletal muscles from dystrophic mice. Neuromuscul. Disord. 11: 260-268.

Ma, Y.Q., Qin, J., Wu, C., and Plow, E.F. 2008. Kindlin-2 (Mig-2): A co-activator of $\beta 3$ integrins. J. Cell Biol. 181: 439-446.

MacArthur, D.G., Seto, J.T., Raftery, J.M., Quinlan, K.G., Huttley, G.A., Hook, J.W., Lemckert, F.A., Kee, A.J., Edwards, M.R., Berman, Y., et al. 2007. Loss of ACTN3 gene function alters mouse muscle metabolism and shows evidence of positive selection in humans. Nat. Genet. 39: 1261-1265.

MacArthur, D.G., Seto, J.T., Chan, S., Quinlan, K.G., Raftery, J.M., Turner, N., Nicholson, M.D., Kee, A.J., Hardeman, E.C., Gunning, P.W., et al. 2008. An Actn3 knockout mouse provides mechanistic insights into the association between $\alpha$-actinin-3 deficiency and human athletic performance. Hum. Mol. Genet. 17: 1076-1086.

Mackinnon, A.C., Qadota, H., Norman, K.R., Moerman, D.G., and Williams, B.D. 2002. C. elegans PAT-4/ILK functions as an adaptor protein within integrin adhesion complexes. Curr. Biol. 12: 787-797.

Maher, P.A., Pasquale, E.B., Wang, J.Y., and Singer, S.J. 1985. Phosphotyrosine-containing proteins are concentrated in focal adhesions and intercellular junctions in normal cells. Proc. Natl. Acad. Sci. 82: 6576-6580.

Maile, L.A. and Clemmons, D.R. 2002a. The $\alpha \mathrm{V} \beta 3$ integrin regulates insulin-like growth factor I (IGF-I) receptor phosphorylation by altering the rate of recruitment of the Srchomology 2-containing phosphotyrosine phosphatase-2 to the activated IGF-I receptor. Endocrinology 143: 4259-4264.

Maile, L.A. and Clemmons, D.R. 2002b. Regulation of insulinlike growth factor I receptor dephosphorylation by SHPS-1 and the tyrosine phosphatase SHP-2. J. Biol. Chem. 277: 8955-8960.

Maile, L.A., Badley-Clarke, J., and Clemmons, D.R. 2003. The association between integrin-associated protein and SHPS-1 regulates insulin-like growth factor-I receptor signaling in vascular smooth muscle cells. Mol. Biol. Cell 14: 35193528.

Maile, L.A., Busby, W.H., Sitko, K., Capps, B.E., Sergent, T., Badley-Clarke, J., and Clemmons, D.R. 2006a. Insulin-like growth factor-I signaling in smooth muscle cells is regulated by ligand binding to the 177CYDMKTTC184 sequence of the $\beta 3$-subunit of $\alpha \mathrm{V} \beta 3$. Mol. Endocrinol. 20: 405-413.

Maile, L.A., Busby, W.H., Sitko, K., Capps, B.E., Sergent, T., Badley-Clarke, J., Ling, Y., and Clemmons, D.R. 2006b. The heparin binding domain of vitronectin is the region that is required to enhance insulin-like growth factor-I signaling. Mol. Endocrinol. 20: 881-892.

Maile, L.A., Capps, B.E., Miller, E.C., Allen, L.B., Veluvolu, U., Aday, A.W., and Clemmons, D.R. 2008. Glucose regulation of integrin-associated protein cleavage controls the response of vascular smooth muscle cells to insulin-like growth factor-I. Mol. Endocrinol. 22: 1226-1237.

Manser, E., Loo, T.H., Koh, C.G., Zhao, Z.S., Chen, X.Q., Tan, L., Tan, I., Leung, T., and Lim, L. 1998. PAK kinases are directly coupled to the PIX family of nucleotide exchange factors. Mol. Cell 1: 183-192.

Marcoux, N. and Vuori, K. 2003. EGF receptor mediates adhesiondependent activation of the Rac GTPase: A role for phosphatidylinositol 3-kinase and Vav2. Oncogene 22: 6100-6106.

Martel, V., Racaud-Sultan, C., Dupe, S., Marie, C., Paulhe, F., Galmiche, A., Block, M.R., and Albiges-Rizo, C. 2001. Conformation, localization, and integrin binding of talin depend on its interaction with phosphoinositides. J. Biol. Chem. 276: 21217-21227.

Martin, K.H., Slack, J.K., Boerner, S.A., Martin, C.C., and Parsons, J.T. 2002. Integrin connections map: To infinity and beyond. Science 296: 1652-1653.

McDonald, P.C., Oloumi, A., Mills, J., Dobreva, I., Maidan, M., Gray, V., Wederell, E.D., Bally, M.B., Foster, L.J., and Dedhar, S. 2008. Rictor and integrin-linked kinase interact and regulate Akt phosphorylation and cancer cell survival. Cancer Res. 68: 1618-1624.

McNamee, H.P., Ingber, D.E., and Schwartz, M.A. 1993. Adhesion to fibronectin stimulates inositol lipid synthesis and enhances PDGF-induced inositol lipid breakdown. J. Cell Biol. 121: 673-678.

Medley, Q.G., Buchbinder, E.G., Tachibana, K., Ngo, H., Serra-Pages, C., and Streuli, M. 2003. Signaling between focal adhesion kinase and trio. J. Biol. Chem. 278: 13265-13270.

Mitra, S.K., Hanson, D.A., and Schlaepfer, D.D. 2005. Focal adhesion kinase: In command and control of cell motility. Nat. Rev. Mol. Cell Biol. 6: 56-68.

Miyamoto, S., Teramoto, H., Gutkind, J.S., and Yamada, K.M. 1996. Integrins can collaborate with growth factors for phosphorylation of receptor tyrosine kinases and MAP kinase activation: Roles of integrin aggregation and occupancy of receptors. J. Cell Biol. 135: 1633-1642.

Monkley, S.J., Zhou, X.H., Kinston, S.J., Giblett, S.M., Hemmings, L., Priddle, H., Brown, J.E., Pritchard, C.A., Critchley, D.R., and Fässler, R. 2000. Disruption of the talin gene arrests mouse development at the gastrulation stage. Dev. Dyn. 219: 560-574.

Montanez, E., Ussar, S., Schifferer, M., Bosl, M., Zent, R., Moser, M., and Fässler, R. 2008. Kindlin-2 controls bidirectional signaling of integrins. Genes \& Dev. 22: 1325-1330.

Moreno, R.J., Messi, M.L., Zheng, Z., Wang, Z.M., Ye, P., D'Ercole, J.A., and Delbono, O. 2006. Role of sustained overexpression of central nervous system IGF-I in the agedependent decline of mouse excitation-contraction coupling. J. Membr. Biol. 212: 147-161.

Mori, S., Wu, C.Y., Yamaji, S., Saegusa, J., Shi, B., Ma, Z., Kuwabara, Y., Lam, K.S., Isseroff, R.R., Takada, Y.K., et al. 2008. Direct binding of integrin $\alpha v \beta 3$ to FGF1 plays a role in FGF1 signaling. J. Biol. Chem. 283: 18066-18075.

Moro, L., Venturino, M., Bozzo, C., Silengo, L., Altruda, F., Beguinot, L., Tarone, G., and Defilippi, P. 1998. Integrins induce activation of EGF receptor: Role in MAP kinase induction and adhesion-dependent cell survival. EMBO $\mathrm{J}$. 17: 6622-6632.

Moro, L., Dolce, L., Cabodi, S., Bergatto, E., Boeri Erba, E., Smeriglio, M., Turco, E., Retta, S.F., Giuffrida, M.G., Venturino, 
M., et al. 2002. Integrin-induced epidermal growth factor (EGF) receptor activation requires $\mathrm{c}-\mathrm{Src}$ and $\mathrm{p} 130 \mathrm{Cas}$ and leads to phosphorylation of specific EGF receptor tyrosines. J. Biol. Chem. 277: 9405-9414.

Moser, M., Nieswandt, B., Ussar, S., Pozgajova, M., and Fässler, R. 2008. Kindlin-3 is essential for integrin activation and platelet aggregation. Nat. Med. 14: 325-330.

Musaro, A., McCullagh, K.J., Naya, F.J., Olson, E.N., and Rosenthal, N. 1999. IGF-1 induces skeletal myocyte hypertrophy through calcineurin in association with GATA-2 and NF-ATc1. Nature 400: 581-585.

Nagy, T., Wei, H., Shen, T.L., Peng, X., Liang, C.C., Gan, B., and Guan, J.L. 2007. Mammary epithelial-specific deletion of the focal adhesion kinase gene leads to severe lobulo-alveolar hypoplasia and secretory immaturity of the murine mammary gland. J. Biol. Chem. 282: 31766-31776.

Nayal, A., Webb, D.J., Brown, C.M., Schaefer, E.M., VicenteManzanares, M., and Horwitz, A.R. 2006. Paxillin phosphorylation at Ser273 localizes a GIT1-PIX-PAK complex and regulates adhesion and protrusion dynamics. J. Cell Biol. 173: 587-589.

Nieswandt, B., Moser, M., Pleines, I., Varga-Szabo, D., Monkley, S., Critchley, D., and Fässler, R. 2007. Loss of talin1 in platelets abrogates integrin activation, platelet aggregation, and thrombus formation in vitro and in vivo. J. Exp. Med. 204: 3113-3118.

Nimnual, A.S., Taylor, L.J., and Bar-Sagi, D. 2003. Redoxdependent downregulation of Rho by Rac. Nat. Cell Biol. 5: 236-241.

Nodari, A., Zambroni, D., Quattrini, A., Court, F.A., D'Urso, A., Recchia, A., Tybulewicz, V.L., Wrabetz, L., and Feltri, M.L. 2007. $\beta 1$ integrin activates Racl in Schwann cells to generate radial lamellae during axonal sorting and myelination. J. Cell Biol. 177: 1063-1075.

Obergfell, A., Eto, K., Mocsai, A., Buensuceso, C., Moores, S.L., Brugge, J.S., Lowell, C.A., and Shattil, S.J. 2002. Coordinate interactions of Csk, Src, and Syk kinases with $\alpha \mathrm{IIb} \beta 3$ initiate integrin signaling to the cytoskeleton. J. Cell Biol. 157: 265275.

O'Donovan, H.C., Kiely, P.A., and O'Connor, R. 2007. Effects of RACK1 on cell migration and IGF-I signalling in cardiomyoctes are not dependent on an association with the IGFIR. Cell. Signal. 19: 2588-2595.

Oh, W.K., Yoo, J.C., Jo, D., Song, Y.H., Kim, M.G., and Park, D. 1997. Cloning of a SH3 domain-containing proline-rich protein, p85SPR, and its localization in focal adhesion. Biochem. Biophys. Res. Commun. 235: 794-798.

Ohta, Y., Hartwig, J.H., and Stossel, T.P. 2006. FilGAP, a rho- and ROCK-regulated GAP for rac binds filamin A to control actin remodelling. Nat. Cell Biol. 8: 803-814.

Otey, C.A., Pavalko, F.M., and Burridge, K. 1990. An interaction between $\alpha$-actinin and the $\beta 1$ integrin subunit in vitro. J. Cell Biol. 111: 721-729.

Oxley, C.L., Anthis, N.J., Lowe, E.D., Vakonakis, I., Campbell, I.D., and Wegener, K.L. 2008. An integrin phosphorylation switch: The effect of $\beta 3$ integrin tail phosphorylation on Dok1 and talin binding. J. Biol. Chem. 283: 5420-5426.

Pankov, R., Cukierman, E., Clark, K., Matsumoto, K., Hahn, C., Poulin, B., and Yamada, K.M. 2003. Specific $\beta 1$ integrin site selectively regulates Akt/protein kinase B signaling via local activation of protein phosphatase 2A. J. Biol. Chem. 278: 18671-18681.

Papagrigoriou, E., Gingras, A.R., Barsukov, I.L., Bate, N., Fillingham, I.J., Patel, B., Frank, R., Ziegler, W.H., Roberts, G.C., Critchley, D.R., et al. 2004. Activation of a vinculin-binding site in the talin rod involves rearrangement of a five-helix bundle. $E M B O$ J. 23: 2942-2951.

Paul, R., Heil, P., Spatz, J.P., and Schwarz, U.S. 2008. Propagation of mechanical stress through the actin cytoskeleton toward focal adhesions: Model and experiment. Biophys. J. 94: 14701482.

Pavalko, F.M. and LaRoche, S.M. 1993. Activation of human neutrophils induces an interaction between the integrin $\beta 2$ subunit (CD18) and the actin binding protein $\alpha$-actinin. $J$. Immunol. 151: 3795-3807.

Payne, A.M., Zheng, Z., Messi, M.L., Milligan, C.E., Gonzalez, E., and Delbono, O. 2006. Motor neurone targeting of IGF-1 prevents specific force decline in ageing mouse muscle. $J$. Physiol. 570: 283-294.

Payne, A.M., Messi, M.L., Zheng, Z., and Delbono, O. 2007. Motor neuron targeting of IGF-1 attenuates age-related external $\mathrm{Ca}^{2+}$-dependent skeletal muscle contraction in senescent mice. Exp. Gerontol. 42: 309-319.

Pelham R.J. and Wang, Y. 1997. Cell locomotion and focal adhesions are regulated by substrate flexibility. Proc. Natl. Acad. Sci. 94: 13661-13665.

Peng, X., Kraus, M.S., Wei, H., Shen, T.L., Pariaut, R., Alcaraz, A., Ji, G., Cheng, L., Yang, Q., Kotlikoff, M.I., et al. 2006. Inactivation of focal adhesion kinase in cardiomyocytes promotes eccentric cardiac hypertrophy and fibrosis in mice. J. Clin. Invest. 116: 217-227.

Peterson, R.T., Desai, B.N., Hardwick, J.S., and Schreiber, S.L. 1999. Protein phosphatase $2 \mathrm{~A}$ interacts with the $70-\mathrm{kDa}$ S6 kinase and is activated by inhibition of FKBP12rapamycin associated protein. Proc. Natl. Acad. Sci. 96: 4438-4442.

Petrich, B.G., Marchese, P., Ruggeri, Z.M., Spiess, S., Weichert, R.A., Ye, F., Tiedt, R., Skoda, R.C., Monkley, S.J., Critchley, D.R., et al. 2007. Talin is required for integrin-mediated platelet function in hemostasis and thrombosis. J. Exp. Med. 204: 3103-3111.

Pirone, D.M., Liu, W.F., Ruiz, S.A., Gao, L., Raghavan, S., Lemmon, C.A., Romer, L.H., and Chen, C.S. 2006. An inhibitory role for FAK in regulating proliferation: A link between limited adhesion and RhoA-ROCK signaling. J. Cell Biol. 174: 277-288.

Plopper, G.E., McNamee, H.P., Dike, L.E., Bojanowski, K., and Ingber, D.E. 1995. Convergence of integrin and growth factor receptor signaling pathways within the focal adhesion complex. Mol. Biol. Cell 6: 1349-1365.

Pollard, T.D. 2007. Regulation of actin filament assembly by Arp2/3 complex and formins. Annu. Rev. Biophys. Biomol. Struct. 36: 451-477.

Postel, R., Vakeel, P., Topczewski, J., Knoll, R., and Bakkers, J. 2008. Zebrafish integrin-linked kinase is required in skeletal muscles for strengthening the integrin-ECM adhesion complex. Dev. Biol. 318: 92-101.

Premont, R.T., Claing, A., Vitale, N., Perry, S.J., and Lefkowitz, R.J. 2000. The GIT family of ADP-ribosylation factor GTPase-activating proteins. Functional diversity of GIT2 through alternative splicing. I. Biol. Chem. 275: 2237322380 .

Priddle, H., Hemmings, L., Monkley, S., Woods, A., Patel, B., Sutton, D., Dunn, G.A., Zicha, D., and Critchley, D.R. 1998. Disruption of the talin gene compromises focal adhesion assembly in undifferentiated but not differentiated embryonic stem cells. J. Cell Biol. 142: 1121-1133.

Pruyne, D., Evangelista, M., Yang, C., Bi, E., Zigmond, S., Bretscher, A., and Boone, C. 2002. Role of formins in actin assembly: Nucleation and barbed-end association. Science 297: 612-615. 
Qian, X., Li, G., Asmussen, H.K., Asnaghi, L., Vass, W.C., Braverman, R., Yamada, K.M., Popescu, N.C., Papageorge, A.G., and Lowy, D.R. 2007. Oncogenic inhibition by a deleted in liver cancer gene requires cooperation between tensin binding and Rho-specific GTPase-activating protein activities. Proc. Natl. Acad. Sci. 104: 9012-9017.

Ratnikov, B., Ptak, C., Han, J., Shabanowitz, J., Hunt, D.F., and Ginsberg, M.H. 2005. Talin phosphorylation sites mapped by mass spectrometry. J. Cell Sci. 118: 4921-4923.

Ravichandran, K.S., Zhou, M.M., Pratt, J.C., Harlan, J.E., Walk, S.F., Fesik, S.W., and Burakoff, S.J. 1997. Evidence for a requirement for both phospholipid and phosphotyrosine binding via the Shc phosphotyrosine-binding domain in vivo. Mol. Cell. Biol. 17: 5540-5549.

Riveline, D., Zamir, E., Balaban, N.Q., Schwarz, U.S., Ishizaki, T., Narumiya, S., Kam, Z., Geiger, B., and Bershadsky, A.D. 2001. Focal contacts as mechanosensors: Externally applied local mechanical force induces growth of focal contacts by an mDial-dependent and ROCK-independent mechanism. I. Cell Biol. 153: 1175-1186.

Robinson, R.C., Turbedsky, K., Kaiser, D.A., Marchand, J.B., Higgs, H.N., Choe, S., and Pollard, T.D. 2001. Crystal structure of Arp2/3 complex. Science 294: 1679-1684.

Rogalski, T.M., Mullen, G.P., Gilbert, M.M., Williams, B.D., and Moerman, D.G. 2000. The UNC-112 gene in Caenorhabditis elegans encodes a novel component of cell-matrix adhesion structures required for integrin localization in the muscle cell membrane. J. Cell Biol. 150: 253-264.

Roovers, K., Davey, G., Zhu, X., Bottazzi, M.E., and Assoian, R.K. 1999. $\alpha 5 \beta 1$ integrin controls cyclin D1 expression by sustaining mitogen-activated protein kinase activity in growth factor-treated cells. Mol. Biol. Cell 10: 3197-3204.

Rusnati, M., Tanghetti, E., Dell'Era, P., Gualandris, A., and Presta, M. 1997. $\alpha \mathrm{v} \beta 3$ integrin mediates the cell-adhesive capacity and biological activity of basic fibroblast growth factor (FGF-2) in cultured endothelial cells. Mol. Biol. Cell 8: 2449-2461.

Sakai, T., Li, S., Docheva, D., Grashoff, C., Sakai, K., Kostka, G., Braun, A., Pfeifer, A., Yurchenco, P.D., and Fässler, R. 2003. Integrin-linked kinase (ILK) is required for polarizing the epiblast, cell adhesion, and controlling actin accumulation. Genes \& Dev. 17: 926-940.

Sander, E.E., ten Klooster, J.P., van Delft, S., van der Kammen, R.A., and Collard, J.G. 1999. Rac downregulates Rho activity: Reciprocal balance between both GTPases determines cellular morphology and migratory behavior. I. Cell Biol. 147: 1009-1022.

Saunders, R.M., Holt, M.R., Jennings, L., Sutton, D.H., Barsukov, I.L., Bobkov, A., Liddington, R.C., Adamson, E.A., Dunn, G.A., and Critchley, D.R. 2006. Role of vinculin in regulating focal adhesion turnover. Eur. J. Cell Biol. 85: 487-500.

Sawada, Y. and Sheetz, M.P. 2002. Force transduction by Triton cytoskeletons. J. Cell Biol. 156: 609-615.

Sawada, Y., Tamada, M., Dubin-Thaler, B.J., Cherniavskaya, O., Sakai, R., Tanaka, S., and Sheetz, M.P. 2006. Force sensing by mechanical extension of the Src family kinase substrate p130Cas. Cell 127: 1015-1026.

Schaller, M.D. and Parsons, J.T. 1995. pp125FAK-dependent tyrosine phosphorylation of paxillin creates a high-affinity binding site for Crk. Mol. Cell. Biol. 15: 2635-2645.

Schaller, M.D., Otey, C.A., Hildebrand, J.D., and Parsons, J.T. 1995. Focal adhesion kinase and paxillin bind to peptides mimicking $\beta$ integrin cytoplasmic domains. J. Cell Biol. 130: $1181-1187$.

Schertzer, J.D., Ryall, J.G., and Lynch, G.S. 2006. Systemic administration of IGF-I enhances oxidative status and reduces contraction-induced injury in skeletal muscles of $\mathrm{mdx}$ dystrophic mice. Am. J. Physiol. Endocrinol. Metab. 291: E499-E505. doi: 10.1152/ajpendo.00101.2006.

Schertzer, J.D., van der Poel, C., Shavlakadze, T., Grounds, M.D., and Lynch, G.S. 2008. Muscle-specific overexpression of IGFI improves E-C coupling in skeletal muscle fibers from dystrophic mdx mice. Am. J. Physiol. Cell Physiol. 294: C161-C168. doi: 10.1152/ajpcell.00399.2007.

Schlaepfer, D.D., Hanks, S.K., Hunter, T., and van der Geer, P. 1994. Integrin-mediated signal transduction linked to Ras pathway by GRB2 binding to focal adhesion kinase. Nature 372: 786-791.

Schober, M., Raghavan, S., Nikolova, M., Polak, L., Pasolli, H.A., Beggs, H.E., Reichardt, L.F., and Fuchs, E. 2007. Focal adhesion kinase modulates tension signaling to control actin and focal adhesion dynamics. J. Cell Biol. 176: 667-680.

Semsarian, C., Sutrave, P., Richmond, D.R., and Graham, R.M. 1999. Insulin-like growth factor (IGF-I) induces myotube hypertrophy associated with an increase in anaerobic glycolysis in a clonal skeletal-muscle cell model. Biochem. J. 339: 443-451.

Serrels, B., Serrels, A., Brunton, V.G., Holt, M., McLean, G.W., Gray, C.H., Jones, G.E., and Frame, M.C. 2007. Focal adhesion kinase controls actin assembly via a FERM-mediated interaction with the Arp2/3 complex. Nat. Cell Biol. 9: 10461056.

Sheppard, D. 2005. Integrin-mediated activation of latent transforming growth factor $\beta$. Cancer Metastasis Rev. 24: 395402.

Simons, K. and Toomre, D. 2000. Lipid rafts and signal transduction. Nature Reviews 1: 31-39.

Simonson, W.T., Franco, S.J., and Huttenlocher, A. 2006. Talin1 regulates TCR-mediated LFA-1 function. I. Immunol. 177: 7707-7714.

Slack-Davis, J.K., Eblen, S.T., Zecevic, M., Boerner, S.A., Tarcsafalvi, A., Diaz, H.B., Marshall, M.S., Weber, M.J., Parsons, J.T., and Catling, A.D. 2003. PAK1 phosphorylation of MEK1 regulates fibronectin-stimulated MAPK activation. J. Cell Biol. 162: 281291.

Small, J.V. and Resch, G.P. 2005. The comings and goings of actin: Coupling protrusion and retraction in cell motility. Curr. Opin. Cell Biol. 17: 517-523.

Sundberg, C. and Rubin, K. 1996. Stimulation of $\beta 1$ integrins on fibroblasts induces PDGF independent tyrosine phosphorylation of PDGF $\beta$-receptors. J. Cell Biol. 132: 741-752.

Tadokoro, S., Shattil, S.J., Eto, K., Tai, V., Liddington, R.C., de Pereda, J.M., Ginsberg, M.H., and Calderwood, D.A. 2003. Talin binding to integrin $\beta$ tails: A final common step in integrin activation. Science 302: 103-106.

Tai, Y.T., Podar, K., Catley, L., Tseng, Y.H., Akiyama, M., Shringarpure, R., Burger, R., Hideshima, T., Chauhan, D., Mitsiades, N., et al. 2003. Insulin-like growth factor-1 induces adhesion and migration in human multiple myeloma cells via activation of $\beta 1$-integrin and phosphatidylinositol 3'-kinase/AKT signaling. Cancer Res. 63: 5850-5858.

Takala, H., Nurminen, E., Nurmi, S.M., Aatonen, M., Strandin, T., Takatalo, M., Kiema, T., Gahmberg, C.G., Ylanne, J., and Fagerholm, S.C. 2008. $\beta 2$ integrin phosphorylation on Thr758 acts as a molecular switch to regulate 14-3-3 and filamin binding. Blood 112: 1853-1862.

Tamada, M., Sheetz, M.P., and Sawada, Y. 2004. Activation of a signaling cascade by cytoskeleton stretch. Dev. Cell 7: 709718.

Tanaka, S., Morishita, T., Hashimoto, Y., Hattori, S., Nakamura, S., Shibuya, M., Matuoka, K., Takenawa, T., Kurata, T., and Nagashima, K. 1994. C3G, a guanine nucleotide-releasing 
protein expressed ubiquitously, binds to the src homology 3 domains of CRK and GRB2/ASH proteins. Proc. Natl. Acad. Sci. 91: 3443-3447.

Tanentzapf, G. and Brown, N.H. 2006. An interaction between integrin and the talin FERM domain mediates integrin activation but not linkage to the cytoskeleton. Nat. Cell Biol. 8: 601-606.

Teis, D. and Huber, L.A. 2003. The odd couple: Signal transduction and endocytosis. Cell. Mol. Life Sci. 60: 2020-2033.

Thomas, J.W., Ellis, B., Boerner, R.J., Knight, W.B., White II, G.C., and Schaller, M.D. 1998. SH2- and SH3-mediated interactions between focal adhesion kinase and Src. J. Biol. Chem. 273: 577-583.

Tu, Y., Kucik, D.F., and Wu, C. 2001. Identification and kinetic analysis of the interaction between nck-2 and DOCK180. FEBS Lett. 491: 193-199.

Tu, Y., Wu, S., Shi, X., Chen, K., and Wu, C. 2003. Migfilin and Mig-2 link focal adhesions to filamin and the actin cytoskeleton and function in cell shape modulation. Cell 113: 37-47.

Tucker, M. and Han, M. 2008. Muscle cell migrations of $C$. elegans are mediated by the $\alpha$-integrin INA-1, Eph receptor VAB-1, and a novel peptidase homologue MNP-1. Dev. Biol. 318: 215-223.

Turner, C.E. 2000. Paxillin and focal adhesion signalling. Nat. Cell Biol. 2: E231-E236. doi: 10.1038/35046659.

Turner, C.E., Brown, M.C., Perrotta, J.A., Riedy, M.C., Nikolopoulos, S.N., McDonald, A.R., Bagrodia, S., Thomas, S., and Leventhal, P.S. 1999. Paxillin LD4 motif binds PAK and PIX through a novel 95-kD ankyrin repeat, ARF-GAP protein: A role in cytoskeletal remodeling. J. Cell Biol. 145: 851-863.

Ussar, S., Moser, M., Widmaier, M., Rognoni, E., Harrer, C., Genzel-Boroviczeny, O., and Fässler, R. 2008. Loss of Kindlin-1 causes skin atrophy and lethal neonatal intestinal epithelial dysfunction. PLoS Genet. 4: e1000289. doi: 10.1371/journal.pgen.1000289.

Vanhaesebroeck, B. and Alessi, D.R. 2000. The PI3K-PDK1 connection: More than just a road to PKB. Biochem. J. 346: 561-576.

van Hengel, J., D'Hooge, P., Hooghe, B., Wu, X., Libbrecht, L., De Vos, R., Quondamatteo, F., Klempt, M., Brakebusch, C., and van Roy, F. 2008. Continuous cell injury promotes hepatic tumorigenesis in cdc42-deficient mouse liver. Gastroenterology 134: 781-792.

van Hennik, P.B., ten Klooster, J.P., Halstead, J.R., Voermans, C., Anthony, E.C., Divecha, N., and Hordijk, P.L. 2003. The Cterminal domain of Rac1 contains two motifs that control targeting and signaling specificity. J. Biol. Chem. 278: 3916639175.

Varga-Szabo, D., Pleines, I., and Nieswandt, B. 2008. Cell adhesion mechanisms in platelets. Arterioscler. Thromb. Vasc. Biol. 28: 403-412.

Vaynberg, J., Fukuda, T., Chen, K., Vinogradova, O., Velyvis, A., $\mathrm{Tu}, \mathrm{Y} ., \mathrm{Ng}, \mathrm{L} ., \mathrm{Wu}, \mathrm{C}$., and Qin, J. 2005. Structure of an ultraweak protein-protein complex and its crucial role in regulation of cell morphology and motility. Mol. Cell 17: 513-523.

Velyvis, A., Vaynberg, J., Yang, Y., Vinogradova, O., Zhang, Y., $\mathrm{Wu}, \mathrm{C}$., and Qin, J. 2003. Structural and functional insights into PINCH LIM4 domain-mediated integrin signaling. Nat. Struct. Biol. 10: 558-564.

von Wichert, G., Haimovich, B., Feng, G.S., and Sheetz, M.P. 2003a. Force-dependent integrin-cytoskeleton linkage formation requires downregulation of focal complex dynamics by Shp2. EMBO J. 22: 5023-5035.

von Wichert, G., Jiang, G., Kostic, A., De Vos, K., Sap, J., and Sheetz, M.P. 2003b. RPTP- $\alpha$ acts as a transducer of mechan- ical force on $\alpha \mathrm{v} \beta 3$-integrin-cytoskeleton linkages. J. Cell Biol. 161: 143-153.

Walker, J.L., Fournier, A.K., and Assoian, R.K. 2005. Regulation of growth factor signaling and cell cycle progression by cell adhesion and adhesion-dependent changes in cellular tension. Cytokine Growth Factor Rev. 16: 395-405.

Wang, H.V., Chang, L.W., Brixius, K., Wickström, S.A., Montanez, E., Thievessen, I., Schwander, M., Müller, U., Bloch, W., Mayer, U., et al. 2008. Integrin-linked kinase stabilizes myotendinous junctions and protects muscle from stress-induced damage. J. Cell Biol. 180: 1037-1049.

Wavreille, A.S. and Pei, D. 2007. A chemical approach to the identification of tensin-binding proteins. ACS Chem. Biol. 2: 109-118.

Webb, D.J., Donais, K., Whitmore, L.A., Thomas, S.M., Turner, C.E., Parsons, J.T., and Horwitz, A.F. 2004. FAK-Src signalling through paxillin, ERK and MLCK regulates adhesion disassembly. Nat. Cell Biol. 6: 154-161.

Wegener, K.L. and Campbell, I.D. 2008. Transmembrane and cytoplasmic domains in integrin activation and proteinprotein interactions. Mol. Membr. Biol. 25: 376-387.

Wegener, K.L., Partridge, A.W., Han, J., Pickford, A.R., Liddington, R.C., Ginsberg, M.H., and Campbell, I.D. 2007. Structural basis of integrin activation by talin. Cell 128: 171-182.

Wei, Y., Yang, X., Liu, Q., Wilkins, J.A., and Chapman, H.A. 1999. A role for caveolin and the urokinase receptor in integrin-mediated adhesion and signaling. J. Cell Biol. 144: 1285-1294.

Wells, R.G. 2008. The role of matrix stiffness in regulating cell behavior. Hepatology 47: 1394-1400.

White, D.E., Kurpios, N.A., Zuo, D., Hassell, J.A., Blaess, S., Mueller, U., and Muller, W.J. 2004. Targeted disruption of $\beta 1$ integrin in a transgenic mouse model of human breast cancer reveals an essential role in mammary tumor induction. Cancer Cell 6: 159-170.

White, D.P., Caswell, P.T., and Norman, J.C. 2007. $\alpha v \beta 3$ and $\alpha 5 \beta 1$ integrin recycling pathways dictate downstream Rho kinase signaling to regulate persistent cell migration. J. Cell Biol. 177: 515-525.

Williams, B.D. and Waterston, R.H. 1994. Genes critical for muscle development and function in Caenorhabditis elegans identified through lethal mutations. J. Cell Biol. 124: 475490.

Woo, S.Y., Kim, D.H., Jun, C.B., Kim, Y.M., Haar, E.V., Lee, S.I., Hegg, J.W., Bandhakavi, S., Griffin, T.J., and Kim, D.H. 2007. PRR5, a novel component of mTOR complex 2, regulates platelet-derived growth factor receptor $\beta$ expression and signaling. J. Biol. Chem. 282: 25604-25612.

Wu, X., Quondamatteo, F., and Brakebusch, C. 2006. Cdc42 expression in keratinocytes is required for the maintenance of the basement membrane in skin. Matrix Biol. 25: 466-474.

Wu, X., Li, S., Chrostek-Grashoff, A., Czuchra, A., Meyer, H., Yurchenco, P.D., and Brakebusch, C. 2007. Cdc42 is crucial for the establishment of epithelial polarity during early mammalian development. Dev. Dyn. 236: 2767-2778.

Xi, X., Flevaris, P., Stojanovic, A., Chishti, A., Phillips, D.R., Lam, S.C., and Du, X. 2006. Tyrosine phosphorylation of the integrin $\beta 3$ subunit regulates $\beta 3$ cleavage by calpain. J. Biol. Chem. 281: 29426-29430.

Xi, G., Maile, L.A., Yoo, S.E., and Clemmons, D.R. 2008. Expression of the human $\beta 3$ integrin subunit in mouse smooth muscle cells enhances IGF-I-stimulated signaling and proliferation. J. Cell. Physiol. 214: 306-315.

Xiao, T., Takagi, J., Coller, B.S., Wang, J.H., and Springer, T.A. 2004. Structural basis for allostery in integrins and binding to fibrinogen-mimetic therapeutics. Nature 432: 59-67. 
Legate et al.

Yano, H., Uchida, H., Iwasaki, T., Mukai, M., Akedo, H., Nakamura, K., Hashimoto, S., and Sabe, H. 2000. Paxillin $\alpha$ and Crk-associated substrate exert opposing effects on cell migration and contact inhibition of growth through tyrosine phosphorylation. Proc. Natl. Acad. Sci. 97: 9076-9081.

Zaidel-Bar, R., Itzkovitz, S., Ma'ayan, A., Iyengar, R., and Geiger, B. 2007. Functional atlas of the integrin adhesome. Nat. Cell Biol. 9: 858-867.

Zamir, E., Katz, B.Z., Aota, S., Yamada, K.M., Geiger, B., and Kam, Z. 1999. Molecular diversity of cell-matrix adhesions. J. Cell Sci. 112: 1655-1669.

Zervas, C.G., Gregory, S.L., and Brown, N.H. 2001. Drosophila integrin-linked kinase is required at sites of integrin adhesion to link the cytoskeleton to the plasma membrane. I. Cell Biol. 152: 1007-1018.

Zhai, J., Lin, H., Nie, Z., Wu, J., Canete-Soler, R., Schlaepfer, W.W., and Schlaepfer, D.D. 2003. Direct interaction of focal adhesion kinase with p190RhoGEF. J. Biol. Chem. 278: 24865-24873.

Zhang, X., Jiang, G., Cai, Y., Monkley, S.J., Critchley, D.R., and Sheetz, M.P. 2008. Talin depletion reveals independence of initial cell spreading from integrin activation and traction. Nat. Cell Biol. 10: 1062-1068.

Zhou, H. and Kramer, R.H. 2005. Integrin engagement differentially modulates epithelial cell motility by RhoA/ROCK and PAK1. J. Biol. Chem. 280: 10624-10635. 


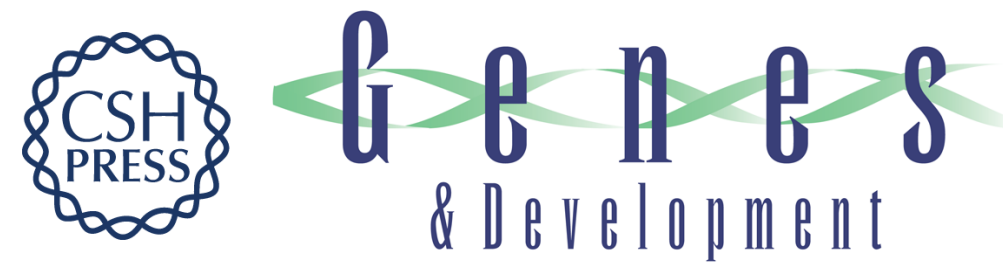

\section{Genetic and cell biological analysis of integrin outside-in signaling}

Kyle R. Legate, Sara A. Wickström and Reinhard Fässler

Genes Dev. 2009, 23:

Access the most recent version at doi:10.1101/gad.1758709

References This article cites 282 articles, 156 of which can be accessed free at: http://genesdev.cshlp.org/content/23/4/397.full.html\#ref-list-1

License

Email Alerting Receive free email alerts when new articles cite this article - sign up in the box at the top Service right corner of the article or click here.

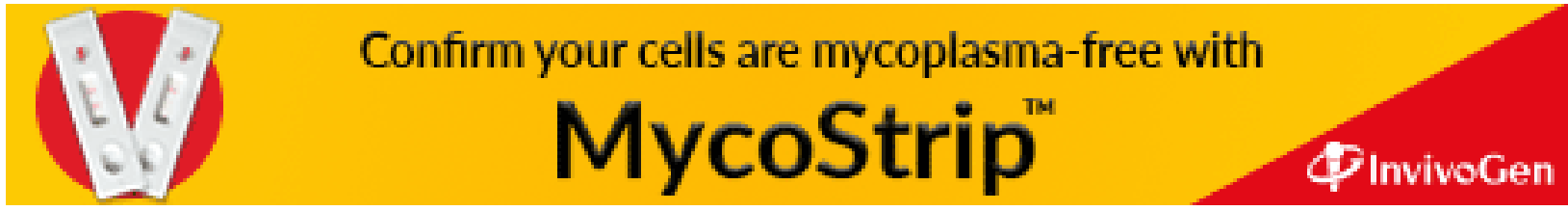

